\title{
The use of fibrinogen
}

\section{in cardiac surgery patients}

Clinical and experimental studies

Katarina Waldén

Department of Anesthesiology and Intensive Care Institute of Clinical Sciences

Sahlgrenska Academy, University of Gothenburg

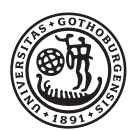

UNIVERSITY OF GOTHENBURG

Gothenburg 2019 
Cover illustration: "Brunt mönster med trianglar" by Andreas Waldén

The use of fibrinogen in cardiac surgery

(C) Katarina Waldén 2019

Katarina.walden@vgregion.se

ISBN 978-91-7833-542-8 (PRINT)

ISBN 978-91-7833-543-5 (PDF)

http://hdl.handle.net/2077/60809

Printed in Gothenburg, Sweden 2019

Printed by BrandFactory 
"Skäms inte för att du är människa, var stolt! Inne i dig öppnar sig valv efter valv oändligt. Du blir aldrig färdig, och det är som det skall." Tomas Tranströmer 



\title{
The use of fibrinogen in cardiac surgery patients Clinical and experimental studies
}

\author{
KATARINA WALDÉN \\ Department of Anesthesiology and Intensive Care, Institute of Clinical \\ Sciences \\ Sahlgrenska Academy, University of Gothenburg, Gothenburg, Sweden \\ ABSTRACT
}

BACKGROUND Cardiac surgery with cardiopulmonary bypass impairs hemostasis due to hemodilution and consumption of platelets and coagulation factors, such as fibrinogen. The aim of this thesis was to study the role of fibrinogen in bleeding complications in cardiac surgery patients. METHODOLOGY Patients who underwent cardiac surgery at Sahlgrenska University Hospital from 2009 to 2017 were included in four studies.. Study I assessed the importance of preoperative plasma fibrinogen concentration for excessive bleeding and the need for red blood cell transfusion in an observational study in 1954 patients. Study II was a double-blinded placebo-controlled study where 48 patients were randomized to prophylactic administration of fibrinogen concentrate or placebo. Primary endpoint was postoperative bleeding volume. Study III was an observational study in 5408 patients that assessed if patients who had received perioperative fibrinogen concentrate due to bleeding had a higher risk of thromboembolic complications or death. Study IV was an in vitro study where fibrinogen concentrate was added to blood samples from 15 patients to investigate if concomitant tranexamic acid and fibrinogen administration has additional effects on clot formation compared to fibrinogen alone.

RESULTS The preoperative plasma fibrinogen concentration correlated inversely to increased postoperative bleeding but not to RBC transfusion. Prophylactic infusion of $2 \mathrm{~g}$ fibrinogen concentrate did not reduce postoperative bleeding volume. Patients who received fibrinogen concentrate due to perioperative bleeding did not have a higher risk of thromboembolic complications or death during the first year after surgery. The combination of tranexamic acid and fibrinogen did not have additional effects on platelet-independent clotting time or clot firmness than fibrinogen alone.

CONCLUSION Preoperative plasma fibrinogen concentration is associated with excessive bleeding after cardiac surgery. Preoperative supplementation with fibrinogen concentrate did not significantly influence postoperative bleeding in low risk patients undergoing coronary artery bypass grafting. Perioperative administration of fibrinogen concentrate in case of bleeding appears safe. The enhancing effects of fibrinogen concentrate on clot firmness in blood samples from cardiac surgery patients was not further increased in the presence of tranexamic acid.

KEYWORDS fibrinogen, cardiac surgery, bleeding, transfusion, thromboembolism, tranexamic acid ISBN 978-91-7833-542-8 (PRINT) 978-91-7833-543-5 (PDF) http://hdl.handle.net/2077/60809 



\section{POPULÄRVETENSKAPLIG SAMMANFATTNING}

Hjärtats och lungornas funktioner kan, vid behov, till exempel under hjärtoperationer, tas över av en så kallad hjärt-lungmaskin. I hjärtlungmaskinen pumpas blodet förbi hjärtat samtidigt som det syresätts. Hjärtat kan då tillfälligt stoppas utan att patientens liv hotas. En nackdel vid användandet av hjärt-lungmaskin är att blodets förmåga att stoppa blödning och samtidigt motverka blodproppar påverkas negativt.

Blodets förmåga att balansera blödning och proppbildning kallas för hemostas. Hemostasen under och efter hjärtkirurgi påverkas av flera faktorer relaterade till både patienten, som till exempel ålder och övrig sjuklighet, samt till vilken typ av kirurgisk metod som används och hur lång tid operationen tar. När man använder en hjärt-lungmaskin måste patientens blod spädas ut och blodet utsätts också för kroppsfrämmande ytor, bland annat plastslangar. Detta drar igång en aktivering och förbrukning av koagulationsfaktorer samt en aktivering av inflammatoriska reaktioner. Denna påverkan på koagulationssystemet kan orsaka allvarlig blödning både under och efter kirurgi och en del patienter kan behöva opereras på nytt på grund av dessa blödningar.

Ungefär hälften av de hjärtkirurgiska patienterna behöver behandlas med blodtransfusion. En akut operation på grund av blödning innebär en ökad risk för sjuklighet och död efter hjärtkirurgi. Det är därför viktigt att kunna förutse och minska dessa blödningskomplikationer. Fibrinogen är den koagulationsfaktor som finns i störst mängd i blodet. Fibrinogen är ett protein som vid aktivering bildar ett nät där blodplättar och röda blodkroppar fastnar och därmed bildas ett koagel på platsen för skadan. Vid större blödning förbrukas tillgängligt fibrinogen och därför har fibrinogenkoncentrat under de senare åren använts allt oftare för att förbättra koagulationen under och efter operationen. Fibrinogenkoncentrat tillverkas av plasma från blodgivare.

Syftet med avhandlingsarbetet är att belysa fibrinogenets roll när det gäller att förutse blödning, om profylaktisk behandling med fibrinogenkoncentrat före operationen minskar blödning, om behandling med fibrinogen till blödande patienter är säker och om fibrinogen tillsammans med standardbehandling med läkemedel som hämmar blodkoaglets nedbrytning, så kallad fibrinolyshämmare, ger förbättrad koagulation. 
I delarbete I undersöktes om det fanns ett samband mellan patienternas fibrinogenkoncentration i blodet före operationen och mängden blödning efter operationen samt behovet av blodtransfusion. Vi fann att patienter med låg fibrinogenkoncentration hade en signifikant ökad risk för allvarlig blödning. Däremot sågs inget samband mellan fibrinogenkoncentration och behovet av blodtransfusioner.

Delarbete II syftade till att undersöka om förebyggande behandling med fibrinogenkoncentrat innan kirurgi kan bidra till att minska blödningsmängden efter operationen. Patienterna delades in i två grupper där den ena gruppen behandlades med fibrinogenkoncentrat och den andra med placebo. Studien kunde inte visa att förebyggande infusion av fibrinogenkoncentrat minskar blödningsmängden efter kranskärlsoperationer.

I delarbete III studerades 5408 patienter som hjärtopererats. Vi jämförde de patienter som erhållit fibrinogenkoncentrat på grund av blödning under eller efter hjärtoperationen med de patienter som inte erhållit detta. Jämförelsen gjordes med avseende på risk att drabbas av blodproppar och död. Patienter som erhållit fibrinogenkoncentrat hade inte en högre risk för blodproppar och död upp till ett år efter kirurgi.

Delarbete IV var en experimentell studie som beskriver effekten av fibrinogentillsats till blodprover som tagits från hjärtkirurgiska patienter före och efter infusion av tranexamsyra. Tranexamsyra är en fibrinolyshämmare, det vill säga ett läkemedel som förhindrar nedbrytning av blodkoagel och därmed minskar blödningar. Tranexamsyra ges rutinmässigt till patienter som hjärtopereras. I studien förbättrade fibrinogentillsats koagelbildning och koagelstyrka i blodproverna, men effekten skiljde sig inte i blodprover som samlats före eller efter att tranexamsyra givits.

Sammanfattningsvis har patienter med låg koncentration av fibrinogen $\mathrm{i}$ blodet en ökad risk för allvarlig blödning efter hjärtkirurgi. Att förebyggande ge fibrinogenkoncentrat till patienter med normala fibrinogennivåer och låg förväntad risk för blödning minskade ej signifikant blödningsmängden när de genomgick kranskärlskirurgi. Användandet av fibrinogenkoncentrat till patienter med pågående blödning i avsikt att förbättra koagulationen förefaller sig säkert och ökar inte risken för blodproppar. Den förstärkta koagelstyrkan som fibrinogenkoncentrat bidrar till i blodprover från hjärtkirurgiska patienter blir inte ytterligare förbättrad i närvaro av fibrinolyshämmare. 


\section{LIST OF PAPERS}

This thesis is based on the following studies, referred to in the text by their Roman numerals.

I. Waldén K, Jeppsson A, Nasic S, Backlund E, Karlsson M. Low preoperative fibrinogen plasma concentration is associated with excessive bleeding after cardiac surgery. Ann Thorac Surg 2014 Apr;97(4):1199-206.

II. Jeppsson A, Waldén K, Roman-Emanuel C, ThimourBergström L, Karlsson M.

Preoperative supplementation with fibrinogen concentrate in cardiac surgery: a randomized controlled study.

Br J Anaesth 2016 Feb;116(2):208-14.

III. Waldén K, Jeppsson A, Nasic S, Karlsson M.

Fibrinogen concentrate administration to cardiac surgery patients with ongoing bleeding does not increase the risk of thromboembolic complications or death.

(Submitted manuscript)

IV. Waldén K, Jeppsson A, Shams-Hakimi C, Karlsson M. Effects of fibrinogen supplementation on clot formation in blood samples from cardiac surgery patients before and after tranexamic acid administration.

Transfus Med 2019 May 22 10.1111/tme .12604 (Epub ahead of print). 


\section{CONTENT}

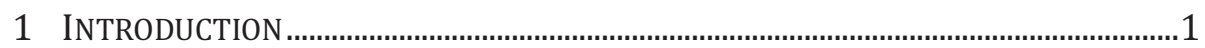

1.1 Overview of the hemostasis and the coagulation system......................1

1.2 Fibrinogen ............................................................................................................

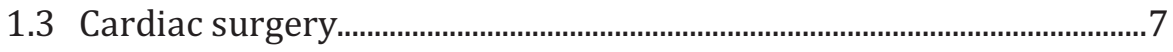

1.4 Study objectives ............................................................................................

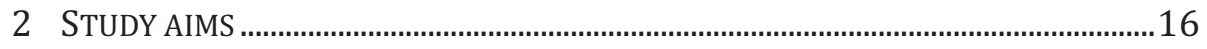

3 PATIENTS AND METHODS.........................................................................................

3.1 Patients ........................................................................................................

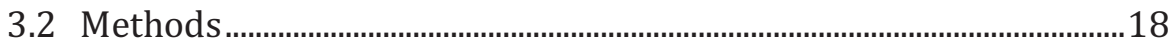

3.3 Statistical analyses.....................................................................................

4 RESULTS ..........................................................................................................27

4.1 Preoperative plasma concentration of fibrinogen, bleeding and

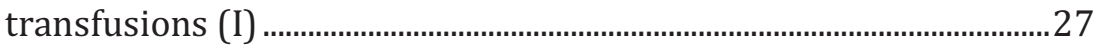

4.2 Prophylactic treatment with fibrinogen concentrate (II) ..................31

4.3 Fibrinogen administration and risk of thromboembolic complications (III).....................................................................................34

4.4 Fibrinogen supplementation and tranexamic acid administration

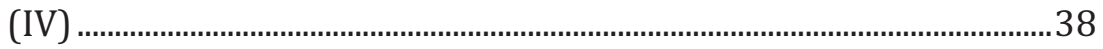

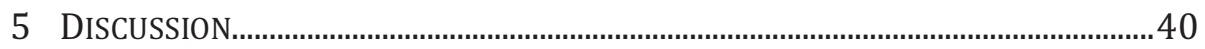

5.1 Fibrinogen concentration, bleeding and transfusions (I)...................40

5.2 Treatment with fibrinogen concentrate (II)...........................................4 42

5.3 Fibrinogen administration and risk of complications (III)................43

5.4 Effects of tranexamic acid and fibrinogen concentrate (IV) .............45

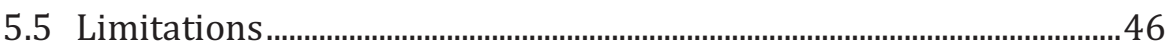

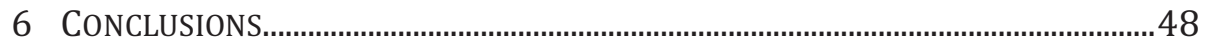

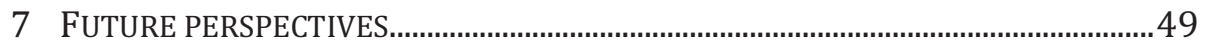

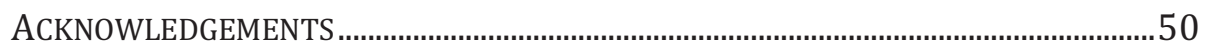

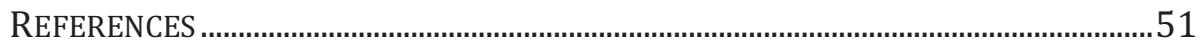




\section{ABBREVIATIONS}

ACT

ANOVA

APTT

ASA

CABG

CI

CPB

CT

DAPT

ECC

GUCH

HCT

HB

HR

LMWH

MCF

ML

OR

PCI

PLT
Activated clotting time

Analysis of variance

Activated partial thromboplastin time

Acetyl salicylic acid (aspirin)

Coronary artery bypass grafting

Confidence interval

Cardiopulmonary bypass

Clotting time

Double anti platelet therapy

Extra corporeal circulation

Grown up congenital heart

Hematocrit

Hemoglobin

Hazard ratio

Low molecular weight heparin

Maximal clot firmness

Maximal lysis

Odds ratio

Percutaneous coronary intervention

Platelets 
PS

Propensity score

PT

Prothrombin time

RBC

Red blood cell

SD

Standard deviation

TXA

Tranexamic acid

vWF

Von Willebrand factor 


\section{INTRODUCTION}

Excessive bleeding is common during and after cardiac surgery. It can be caused both by the surgical trauma and by an impaired hemostasis. It is of great importance to address the causes to reduce complications related to bleeding. The coagulation factor fibrinogen is the substrate in the coagulation system with the highest plasma concentration and essential in blood clot formation. However, there is limited knowledge about the role of fibrinogen to predict and prevent bleeding in cardiac surgery.

\subsection{OVERVIEW OF THE HEMOSTASIS AND THE COAGULATION SYSTEM}

In the presence of a vascular injury, there is an immediate response by smooth muscle cells in the vessel wall, initiated by sympathetic receptors. This causes a vasoconstriction at the site of injury, reducing the blood flow through the injured area. In the damaged vessel, subendothelial cells and collagen are exposed to plasma. The von Willebrand factor (vWF), a protein circulating in plasma, binds to receptors on the exposed collagen. Further on, vWF attracts platelets to the site, which connects to vWF through receptors (Ib) on their surface. This activates the platelets, making them change shape and stimulates to degranulation. The release of adenosine diphosphate (ADP), calcium (Ca) thromboxane A2 (TXA2) and thrombin promotes attraction, activation and adhesion of more platelets. Additional vWF, fibrinogen and coagulation factor V and XIII are also released. Fibrinogen, readily circulating in plasma and released from platelets, binds to activated glycoprotein receptor IIb/IIIa (GPIIb/IIIa) on the platelet surface, forming a rather weak plug (1-3).

At the site of injury tissue factor (TF), a glycoprotein, expressed by subendothelial and perivascular cells is exposed. TF and its interaction with circulating coagulating factor VII in plasma, initiate a chain reaction that activates several other coagulation factors. These coagulation factors interact with activated platelets and forms a complex both attached to the vessel wall and directly to the platelets. The product of this cascade is an extensive conversion of prothrombin to thrombin. Thrombin cleaves fibrinogen to fibrin, as well as activates factor XIII. Together, fibrin and factor XIII, form a stable network and a mature blood clot is achieved. 
During this process, circulating red blood cells (RBCs) are trapped in the clot $(1,4,5)$.

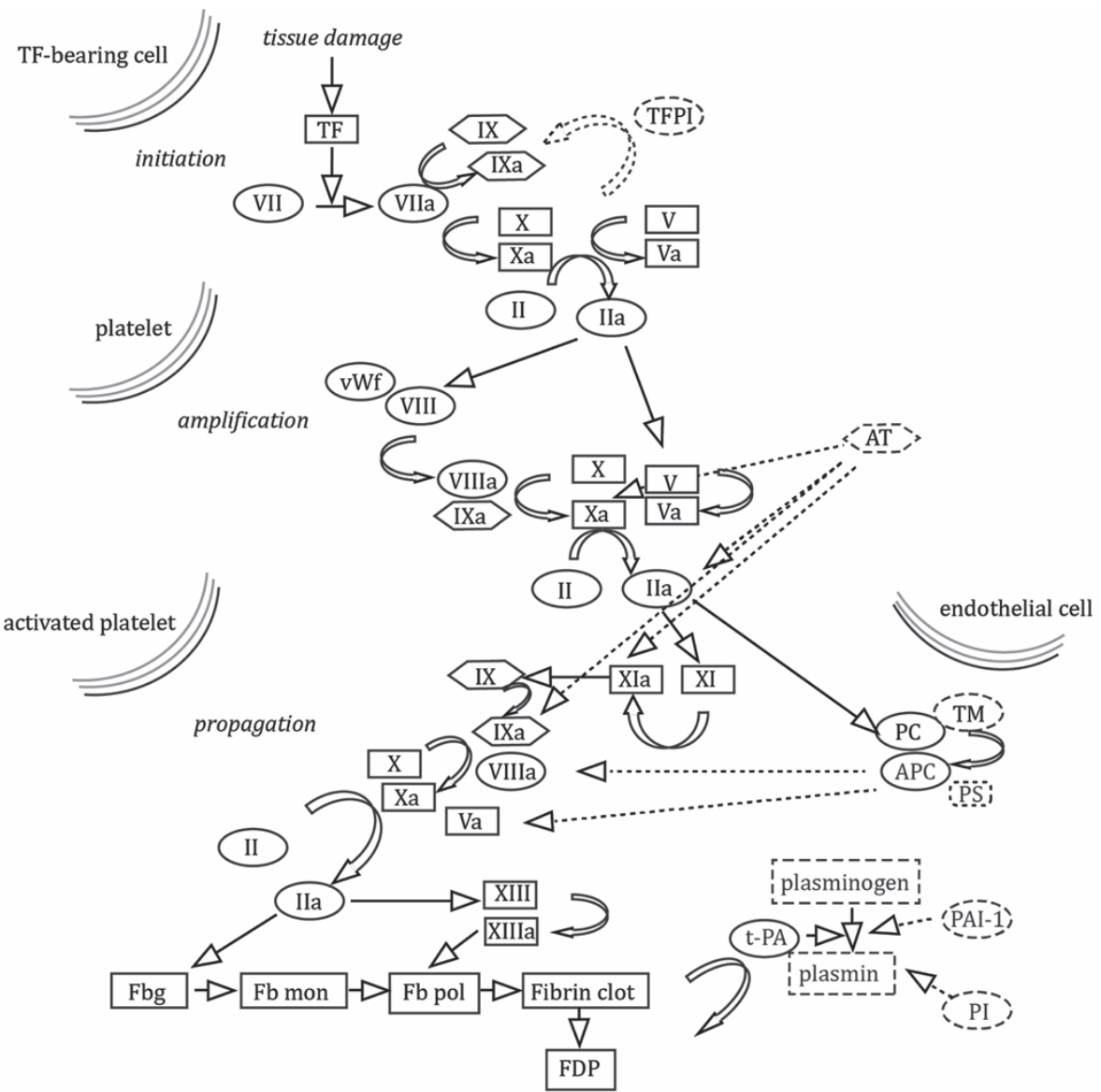

Figure 1. Illustration of the coagulation cascade where the end product is an insoluble fibrin clot. Image with the courtesy of Aleksandra Antovic, Dept. of Medicine, Karolinska Institute. 


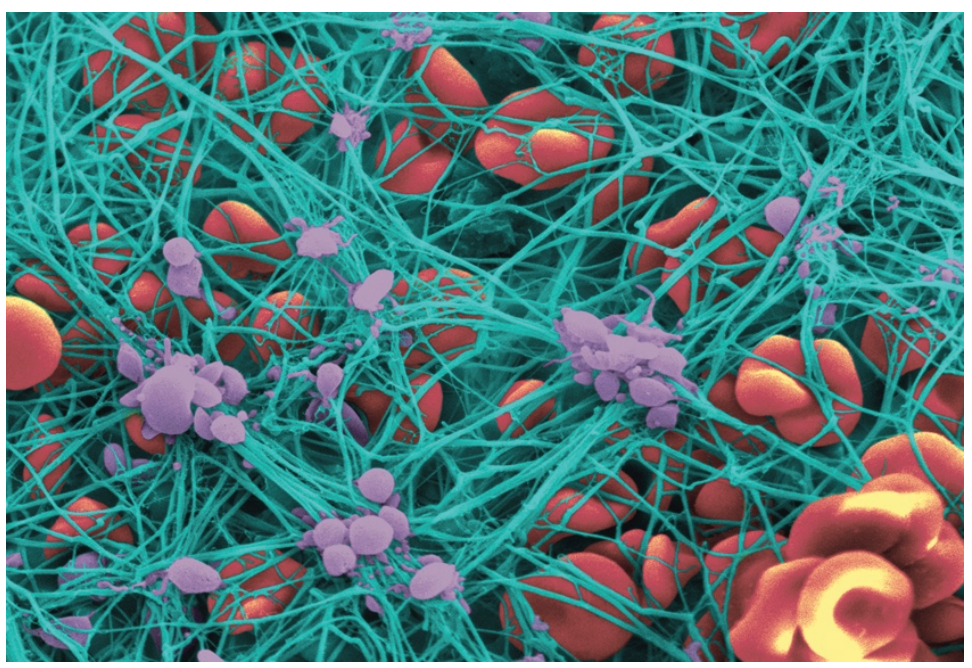

Figure 2. Colorized scanning electron micrograph of a whole blood clot. Fibrin strands in green, platelets in purple and red blood cells (RBCs) in red. Image with the courtesy of Yuri Veklich and John W Weisel, Dept. of Cell and Developmental Biology, Perelman School of Medicine, University of Pennsylvania.

\subsection{FIBRINOGEN}

The glycoprotein fibrinogen is also known as coagulation factor I. It was discovered over 350 years ago when Malphigi in 1666 describes the fibrin strands in a microscope. During the $19^{\text {th }}$ century, Virchow named the protein fibrinogen and later in the $19^{\text {th }}$ century, Hammarsten was able to purify it (6).

Fibrinogen has a molecular weight of 340 kilodalton $(\mathrm{kDa})$ and is a key factor in the human coagulation system (7). Approximately 2-5 g of fibrinogen is synthesized daily the by the hepatic cells in the liver. The same quantity is catabolized through normal protein degradation, the coagulation process and other unidentified pathways (8). Fibrinogen has an estimated half time of three to four days (9). The plasma concentration in healthy humans is approximately $1.8-4.5 \mathrm{~g} / \mathrm{L}$ depending on measurement device and reagent $(8,10)$. The concentration is usually determined by the Clauss method which measures coagulation time in diluted plasma in the presence of excess thrombin, an environment where 
the amount of fibrinogen is the limiting factor and coagulation time is inversely proportional to fibrinogen concentration $(11,12)$.

Fibrinogen is a physiological substrate for thrombin, factor XIII and plasmin. A fibrinogen molecule is a dimer containing pairs of chains linked together with disulfide bridges. These chains are cleaved by thrombin, thus releasing fibrinopeptides from the terminals, forming fibrin. The fibrin molecules begin to assemble to form fibrin polymers. These fibrin polymers are further crosslinked and stabilized by activated factor XIII, forming branched fibrin fibers $(13,14)$. The fibrin clot is degraded by plasmin. As mentioned above, fibrinogen also supports platelet aggregation in primary hemostasis by acting as a ligand to GPIIb/IIIa, which is expressed on the surface of activated platelets (14).

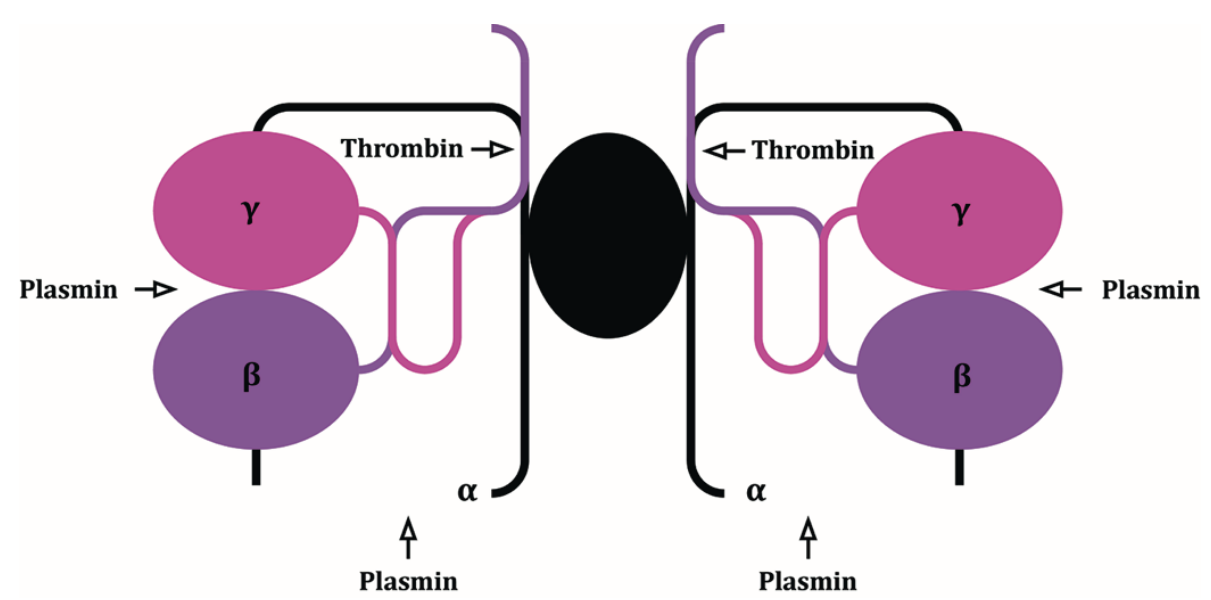

Figure 3. Schematic illustration of a fibrinogen molecule. 


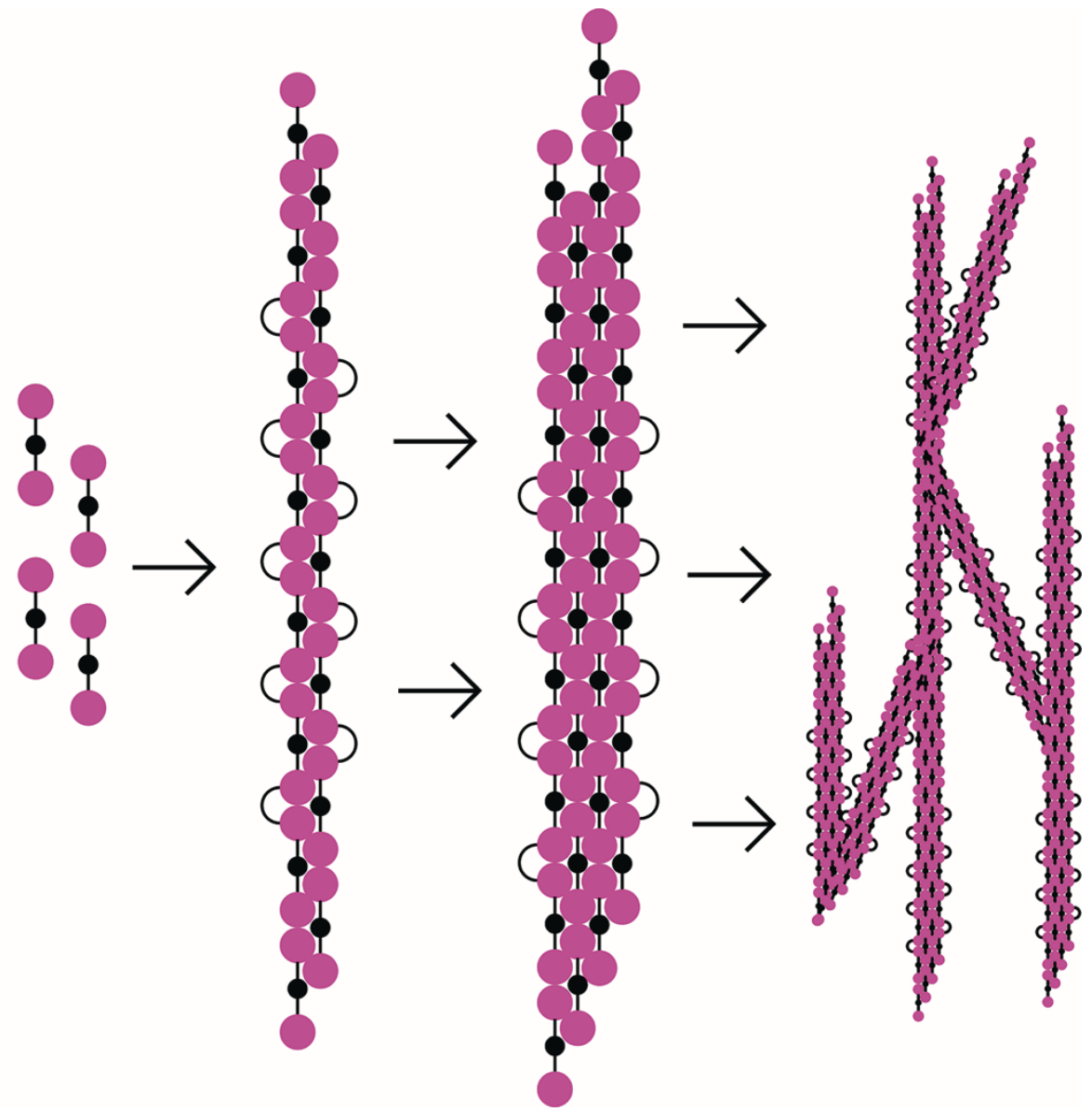

Figure 4. Schematic illustration of fibrin assembling. Upon fibrinogen peptide cleavage by thrombin, fibrin monomers assemble to form fibrin polymers. During this process, activated FXIII stabilizes peptide bond formation between the fibrin polymers, forming branched, crosslinked, stable fibrin fibres.

Besides its hemostatic effect, fibrinogen is an acute phase reactant and regulates inflammatory responses (15). Fibrinogen and its degradation products have multiple receptors which interact with and activate a wide range of immune cells, both in the blood stream and in the perivascular space (15). Fibrinogen plasma levels are normally elevated with age, in females and during pregnancy and are also associated with lifestyle factors such as tobacco- and alcohol use (16). Epidemiological studies have shown a strong association between elevated fibrinogen 
concentration and the risk of major cardiovascular disease and mortality, but a causal relationship has not been established $(16,17)$.

\section{Hypofibrinogenemia}

The presence of low levels of circulating fibrinogen, hypofibrinogenemia, may have different causes. Acquired hypofibrinogenemia is most frequently caused by consumption of clotting factors due to bleeding and in cases of hemodilution. It may also be present in patients with reduced synthesis due to hepatic failure as well as in acute leukemia (18).

In major hemorrhage, fibrinogen is one of the coagulation factors that first fall to critical levels, since the increase in synthesis rate is most often insufficient to compensate the use and breakdown of the coagulation factor (19-21). Further on, acidosis and hypothermia that accompany massive bleeding, induce coagulopathy and seem to aggravate an increased breakdown and decreased synthesis of the coagulation factor (22). Hemodilution due to volume resuscitation further reduces available fibrinogen in plasma, causing reduced clot stability $(23,24)$. Bleeding and hypofibrinogenemia seem to be related to both increased morbidity and mortality in both trauma and in the postoperative setting (25-27).

Congenital disorders of fibrinogen are rare. It can present as hypofibrinogenemia, dysfibrinogenemia and afibrinogenemia and the severity of symptoms is dependent upon the level of dysfunction or deficiency of fibrinogen. It can be as little as no symptoms at all to fatal hemorrhages (28). Major and spontaneous bleeding is generally reported in patients with hypofibrinogenemia and a plasma level below $0.5 \mathrm{~g} / \mathrm{L}$ and patients with a level over $1 \mathrm{~g} / \mathrm{L}$ do not generally experience unprovoked bleeds $(29,30)$. Contractively, the incidence of both venous and arterial thrombosis among these patients is elevated. The reason is not completely understood, but seems to be a cause of excess thrombin generated in absence of fibrinogen. The thrombin is instead available for platelet activation and aggregation, leading to a large and loosely packed platelet thrombus (31-33).

\section{Treatment of hypofibrinogenemia}

There are three different ways to administer fibrinogen: plasma, cryoprecipitate and fibrinogen concentrate. Plasma for transfusions contains about 1-3 g fibrinogen per litre. Large doses are therefore 
required to restore a fibrinogen deficit and supplementation with plasma is often accompanied by a risk of hypervolemia (34). If the target level of fibrinogen concentration is higher than that of the administered plasma, it cannot be reached $(35,36)$. Cryoprecipitate is produced from plasma by precipitating the coagulation factors FVIII, vWF and fibrinogen by their weight. The concentration of fibrinogen in cryoprecipitate is about $16 \mathrm{~g} / \mathrm{L}$ (27). Since the product is constituted by plasma from multiple donors and does not undergo any antiviral processing, it has been withdrawn for safety concerns in several European countries, but is still widely used in the United States and in the United Kingdom (37). Pasteurized fibrinogen concentrate is derived from human plasma and is delivered as a freezedried powder and dissolved to a concentration of about $20 \mathrm{~g} / \mathrm{L}$. Fibrinogen is processed through viral inactivation processes, which also remove antigens and antibodies that reduce the risk of immunological and allergic reactions (38). Fibrinogen concentrate has been commercially available since the 1960's for prophylaxis and treatment of bleeding episodes in patients with congenital hypo- or afibrinogenemia. In these patients, supplementation is usually made below $1 \mathrm{~g} / \mathrm{L}$, since this level seems to be sufficient to keep hemostasis when no other coagulation deficiency is present (31).

In recent years, infusion of fibrinogen concentrate has become an established method to treat patients with ongoing bleeding after surgery and trauma $(39,40)$. For decades, a plasma concentration of above $1 \mathrm{~g} / \mathrm{L}$ was considered to be enough for effective clot formation and maintaining hemostasis even in patients with acquired hypofibrinogenemia due to bleeding $(19,41)$. However, in situations of major bleeding, more recent data suggests that a higher plasma concentration of fibrinogen and a more liberal use of fibrinogen concentrate might be desirable to restore or improve hemostasis $(35,42,43)$.

\subsection{CARDIAC SURGERY}

In the late $19^{\text {th }}$ century, the first reported successful suture on a human heart was reported (44). The gained knowledge of the importance of sterile technique and development of anesthesia helped to make the procedure successful (44). In the 1950's, the development of the cardiopulmonary bypass (CPB), i.e. heart-lung machine, together with the start of commercial manufacture of the anticoagulant heparin paved the way for open heart surgery. CPB and anticoagulation with heparin 
facilitated extracorporeal circuits without deleterious clot formation and thereby the "modern" cardiac surgery was born (45). Since then, the development of techniques has made it possible to perform surgery on e.g. valves, coronary arteries and complex congenital heart defects.

The use of CPB provides a bloodless field during cardiac surgery. The CPB circuit consists of pumps, tubing, cannulas, reservoir, oxygenator, heat exchanger and an arterial line filter, described in Figure 5.

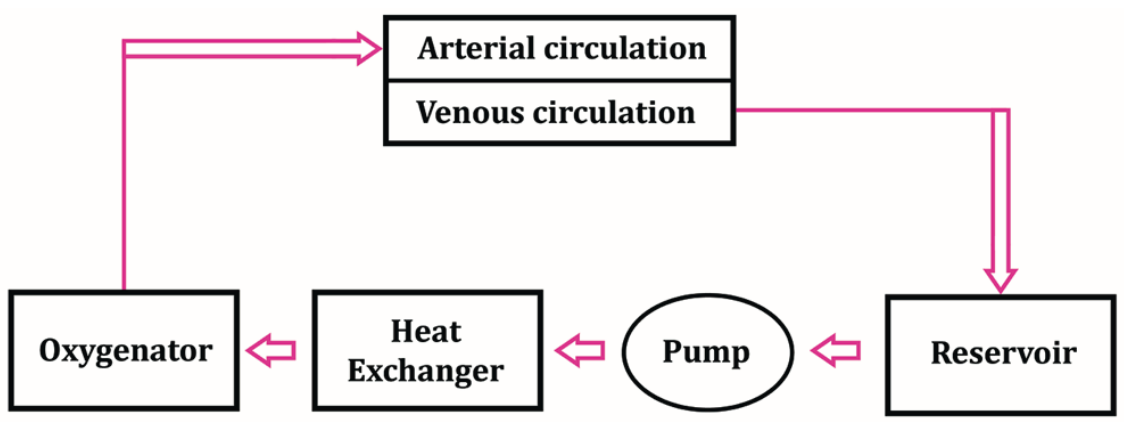

Figure 5. The CPB circuit. Venous blood is drained either from the right atrium or from $v$. cava superior and inferior. Through gravity, the venous blood drains into a reservoir. The roller pump moves blood from the reservoir, through a heat exchanger to an oxygenator. After oxygenation, the blood returns to the arterial circulation through a cannula in the aorta.

In 2017, 5800 open cardiac surgery procedures were performed in Sweden, compared to nearly 9400 in the early 1990's (46). The decline in the number of procedures is largely due to the progress of endovascular treatment by percutaneous coronary interventions (PCI) in patients with coronary artery disease. Despite this, cardiac surgery as a treatment of coronary artery disease and valvular disease is still a needed intervention in selected patients with more complicated disease. The number of open heart surgery has been fairly constant since 2013. Coronary artery bypass grafting (CABG) accounts for $45 \%$, isolated valve surgery for $25 \%$ and a combined CABG and valve surgery for $9 \%$ of all cardiac procedures in Sweden (46).

The 30 -day mortality is about $2.5 \%$ after cardiac surgery (46). There are still substantial risks of complications after cardiac surgery such as bleeding, stroke, renal and heart failure as well as pulmonary dysfunction (47-54). 


\section{Cardiac surgery and bleeding}

Postoperatively, the bleeding volume is measured using chest tubes, inserted in the pleura and pericardium at the end of surgery. Postoperatively, a cardiac surgery patient may be expected to bleed about 500-1000 ml. The drainage is usually removed the day after surgery. Bleeding can be caused by the surgical trauma, impaired hemostasis or both. Hemostasis during and after surgery is influenced by several factors, some of which are patient related, while others are related to the surgical procedure. The use of CPB induces activation of the hemostatic system, mostly because of the contact between the patient's blood and the artificial surfaces of the circuit. This leads to enhanced platelet activation, increased fibrinolysis and substantial inflammatory response interacting with the coagulation system $(55,56)$. The required hemodilution further lowers the concentration of coagulation factors $(57,58)$. Preoperative medication with anticoagulants and antiplatelet therapy may also contribute to the compromised hemostasis (59).

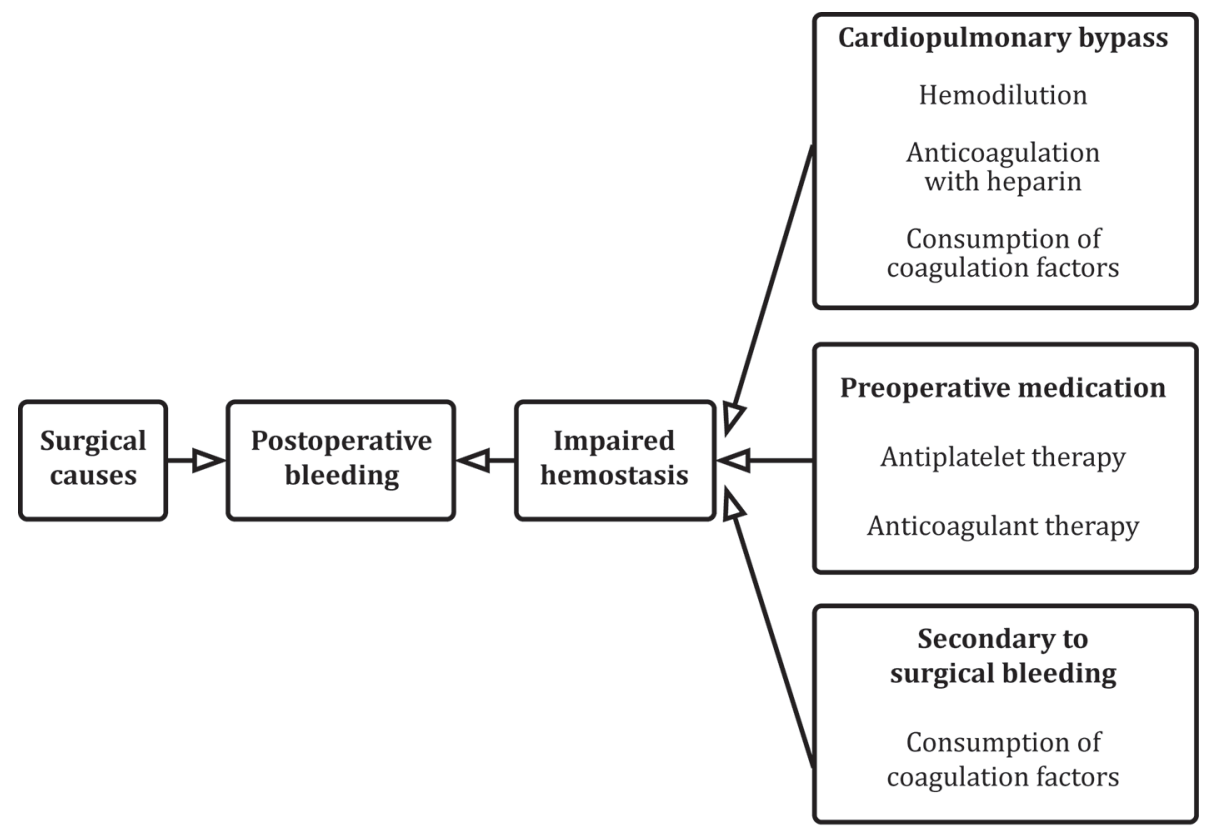

Figure 6. Overview of factors causing postoperative bleeding in cardiac surgery.

Factors involve the surgical trauma, impaired hemostasis or both. 
Despite progress in surgical techniques and the gained understanding of factors affecting perioperative hemostasis, approximately one in twenty patients is still in need of re-exploration due to bleeding $(46,60)$, where a surgical cause of bleeding is found in $60-80 \%$ of the cases $(60,61)$. This leaves a substantial fraction of patients with bleeding due to coagulopathy, where surgical intervention may be avoided if effective countermeasures are initiated. Re-exploration for bleeding is an independent risk factor for increased morbidity and mortality after cardiac surgery and data suggest a two to threefold increase in the risk of death after re-exploration $(62,63)$. Major bleeding in itself and the reoperation due to bleeding increase the risks of renal failure and arrythmias, as well as the risk of prolonged ventilatory support and prolonged stay at the intensive care unit (64-66).

\section{Blood transfusions in cardiac surgery}

Transfusion of blood products is common in cardiac surgery where the use in case of severe bleeding is lifesaving. However, blood transfusions may involve undesirable adverse effects. Today, the risk of transmission of infectious agents is low, but cannot be completely ignored. Immunologic reactions of varying degree, such as hemolysis and anaphylaxis as well as transfusion related lung injury (TRALI) and transfusion associated circulatory overload (TACO) are detrimental side effects. Fatal reactions are rare, occurring in about one in 200000 400000 transfused units (67). When stored in a blood bank, the cells do change properties. After a few days, red blood cells gradually lose the ability to bind, transport and deliver oxygen to the tissues, mostly due to a reduction in 2,3-diphosphoglycerate (2,3-DPG) and altered deformability (68). The clinical implications of these so called "storage lesions" are debated, where older RBC's have been suggested to cause more harm than fresh ones (69). However, recent studies have not been able to find associations between length of storage of the RBCs and mortality, nor any increased risk of adverse events such as renal failure, infections, stroke, embolisms, thrombosis or respiratory failure as previously described $(70,71)$.

The prevalence of transfusions differs extensively between institutions and reported transfusion rates do vary between $10-85 \%(72,73)$ but are usually around 50-60\%. Most of the transfused blood products are allocated to about one fifth of the patients, receiving massive transfusions 
(74). Recognized risk factors for the need of allogenic blood transfusion in cardiac surgery are preoperative anemia, the need for re-sternotomy or acute surgery, low body mass index, higher age and preoperative use of drugs affecting hemostasis (74). Since avoidance of unnecessary transfusions is of high priority, not only due to undesireble side effects, but also has health economic benefits, determining safe thresholds for transfusion is crucial. In observational retrospective studies, transfusion of blood products have been associated with poor outcome and reductions of avoidable transfusions during and after cardiac surgery have been suggested to reduce both morbidity and mortality (75-77). On the contrary, recent data from two large randomized studies of restrictive versus liberal transfusion strategies after cardiac surgery did not establish any difference in their primary outcome regardless of transfusion approach $(78,79)$, although older patients ( $>75$ years) seem to benefit from a more restrictive strategy (78).

\section{Treatment with antifibrinolytics in cardiac surgery}

The use of anti-fibrinolytic drugs is widespread in cardiac surgery, since they have been shown to significantly reduce blood loss and allogenic blood transfusion (80). The use also seems to lower the rate of reoperations due to bleeding (81). A causal relationship between the use of antifibrinolytics and mortality has not been established. At our institution, tranexamic acid (TXA) is used as a routine pre- and post-CPB. TXA is usually well tolerated, and has a low incidence of side effects, including thromboembolic complications $(80,81)$.

TXA prevents the activation of plasminogen to plasmin (82). Consequently, the degradation of fibrin clots is inhibited, Figure 7. The action is mainly competitive, but can be non-competitive with high doses. The inhibition of plasmin generation and activation also seem to reduce plasmin induced platelet activation during CPB $(83,84)$. Patients receiving TXA perioperatively appear to have a lower grade of inflammatory response postoperatively, which may be a result from reduced fibrinolysis. During $\mathrm{CPB}$, a reduced fibrinolysis leads to a lower plasmin activity along with attenuated plasmin activated pro inflammatory cytokines and complement proteins (85-87). Furthermore, TXA may partly improve platelet aggregation in patients treated with acetyl salicylic acid and clopidogrel due to a mechanism not yet established (88). 


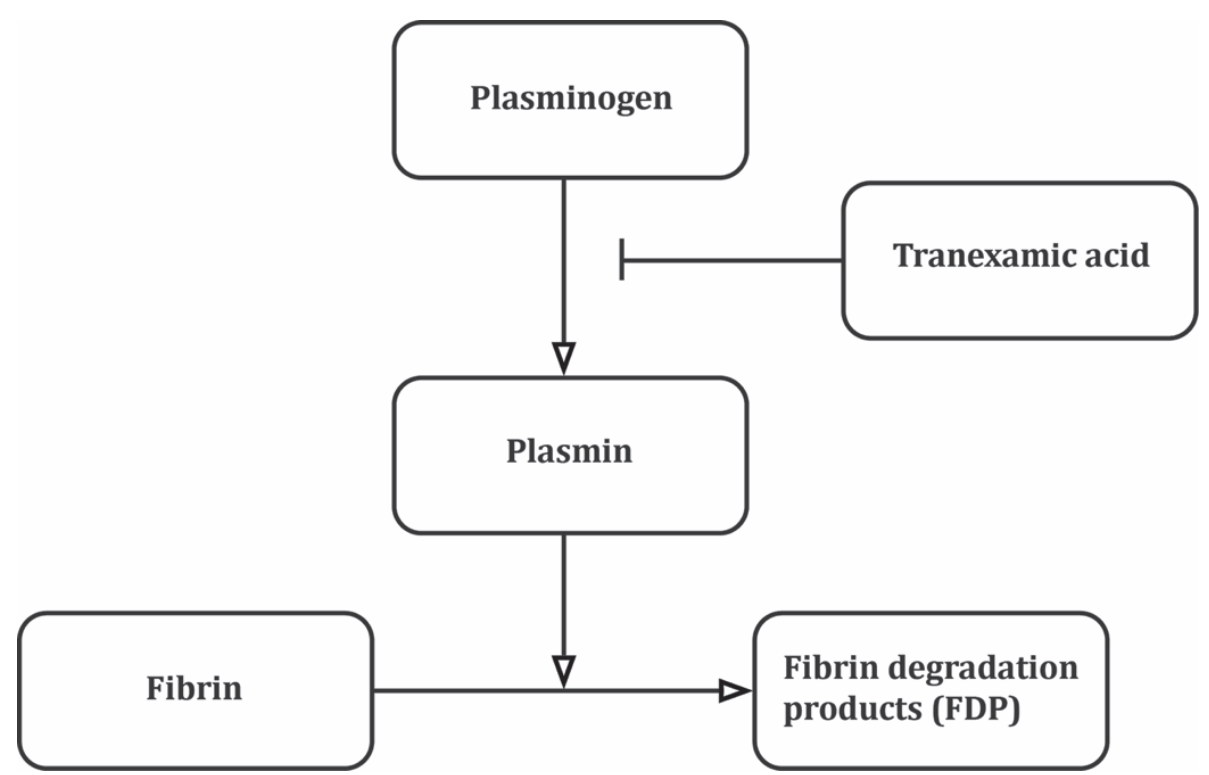

Figure 7. In the fibrinolytic process, fibrin is degraded by plasmin. TXA inhibits the activation of plasminogen to plasmin, thus inhibiting fibrinolysis.

\section{Thromboelastometry in cardiac surgery}

In the case of substantial perioperative bleeding, it is important to differentiate between a surgical and a coagulopathic cause. The development of bedside methods to assess coagulation has increased in interest during the last decade since it allows evaluation of the coagulation and can address type of coagulopathy within minutes. Thromboelastometry (ROTEM ${ }^{\circledR}$ ) is a viscoelastic analysis method to assess blood coagulation in real time, a technique first described in 1948 (89). A small blood sample is analyzed regarding clot formation, strength and lysis by a rotating sensor in the sample tube. As the viscoelastic strength of the blood sample increases, the sensor is exposed to an increasingly larger force. The result is presented as a graphical reaction curve showed in Figure 8 (90). A clot formation dysfunction leading to coagulopathy can be evaluated after 10-15 minutes in comparison to standard coagulation tests in which the response time can be approximately 60 minutes (91). To evaluate the contribution of fibrinogen to the clot, the analysis ROTEM ${ }^{\circledR}$ FIBTEM is used, where platelets are inactivated by cytochalasin D. In cardiac surgery, thromboelastometry guided transfusion protocols are associated with reduced blood loss and 
the need for transfusion of blood products in bleeding patients $(92,93)$, but there is yet to establish whether ROTEM $^{\circledR}$-guided transfusion protocols result in reduction in morbidity or mortality.
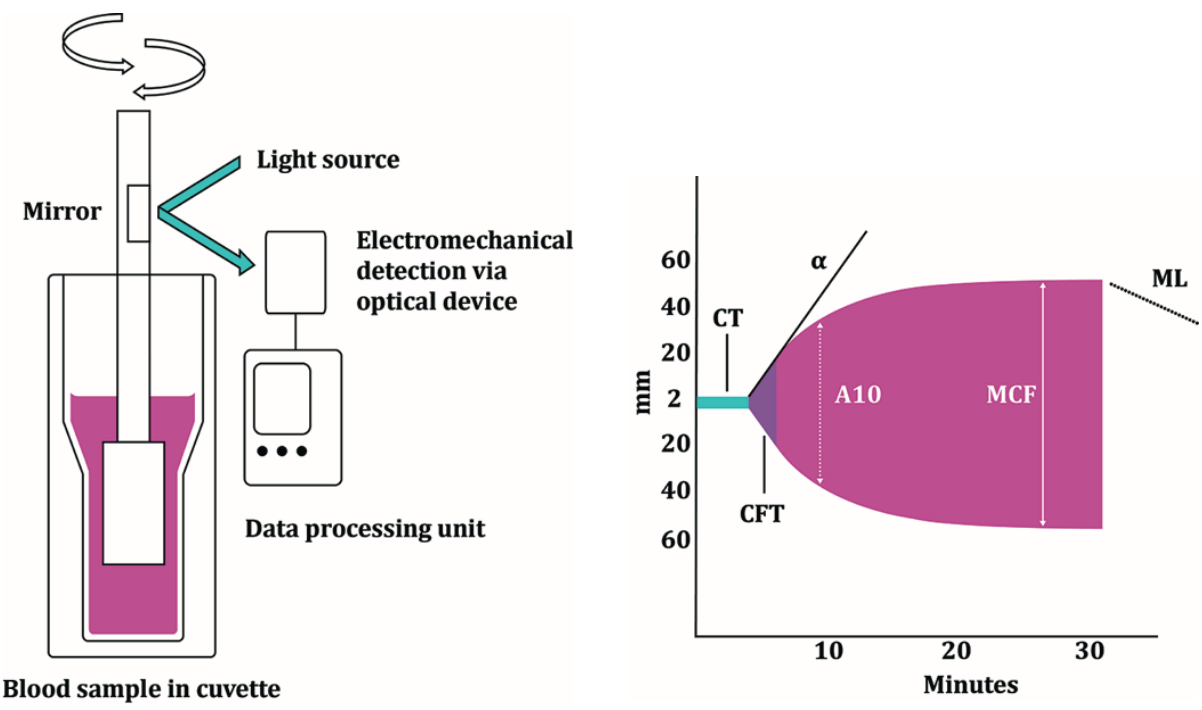

Figure 8. Illustration of the thromboelastometry instrument and an example of a graph. CT (clotting time) = the time it takes for the initial trace of coagulation to reach $2 \mathrm{~mm}, \mathrm{CFT}$ (clot formation time)= the time it takes for the clot amplitude to increase from 2 to $20 \mathrm{~mm}, \mathrm{MCF}$ (maximum clot lysis)= the peak amplitude of the clot, $M L$ (maximum lysis)= percent reduction in $M C F$.

\subsection{STUDY OBJECTIVES}

Excessive bleeding and re-operation due to bleeding after cardiac surgery remain a risk factor for increased morbidity and mortality $(62-64,94)$. Being able to identify patients with increased risk of bleeding complications is appealing as it may reveal possibilities to undertake preventative actions. There has been an increasing interest in the relationship between bleeding and plasma concentrations of individual coagulation factors. Several small studies found a significant correlation between preoperative plasma fibrinogen concentration and bleeding volume (95-101), whereas others did not (102-104).

In a previous study from our group, preoperative plasma level of fibrinogen was shown to be an independent risk factor, not only for postoperative bleeding but also for blood transfusion in patients 
undergoing elective CABG (100). The study had obvious limitations due to the small-sample size and was conducted on an isolated cohort of elective CABG patients with a low risk of peri- and postoperative bleeding. In the light of the above, our objective in study I was to investigate the potential correlation between preoperative plasma fibrinogen levels and postoperative bleeding complications and transfusions in a larger study population consisting of various types of cardiac surgery procedures. A prospective observational study was designed where plasma fibrinogen concentration was measured the day before surgery and evaluated the correlation between fibrinogen concentration and bleeding volume and transfusion of RBC's. In addition, we sought to determine other risk factors for excessive bleeding and transfusions.

To further investigate the role of fibrinogen in postoperative bleeding, a small pilot study $(n=20)$, to test the tolerability and feasibility of prophylactic administration of fibrinogen concentrate to CABG patients with low-normal preoperative plasma fibrinogen concentration, has been performed at our centre. In that study, there were no adverse events related to fibrinogen supplementation and the intervention seemed to reduce the postoperative bleeding volume (105). The study was conducted on a limited number of patients without placebo control, since infusion of fibrinogen to patients without ongoing bleeding had not been studied before. In study II, our objective was therefore to confirm the safety and efficacy of prophylactic fibrinogen infusion in patients with fibrinogen levels in the lower normal range undergoing CABG. For this purpose, a randomized placebo-controlled double-blinded single centre study was designed, where the primary endpoint was postoperative bleeding volume.

The use of fibrinogen concentrate to reduce bleeding in patients undergoing cardiac surgery has increased rapidly but little is known about potential side effects and the possible risk of thromboembolic events among patients with acquired hypofibrinogenemia. Data based on spontaneous reports of side effects when fibrinogen concentrate is used, mainly in patients with hereditary hypofibrinogenemia, indicates a beneficial safety profile, with a low incidence of adverse drug reactions such as thromboembolic events (106). More recent reports in acquired hypofibrinogenemia cardiovascular surgery patients have shown diverging results. Two studies confirm the beneficial results $(107,108)$, but one study reports an association between fibrinogen concentrate administration and ischemic stroke (109). Hence, the study objective in study III, was to retrospectively explore the safety of administrating 
fibrinogen concentrate to cardiac surgery patients in a large study population.

The use of antifibrinolytics, such as TXA, reduces both peri- and postoperative blood loss and the need for transfusion of blood products in cardiac surgery $(80,81)$. Consequently, both fibrinogen and TXA improve hemostasis but it is not known whether these procoagulants have additional effects on hemostasis when administered concomitantly, compared to what can be achieved individually. In study IV, an in vitro study was designed, hypothesising that the effect of fibrinogen combined with TXA to blood samples from cardiac surgery patients may have an additive pro-coagulant effect compared to fibrinogen alone. 


\section{STUDY AIMS}

I. To investigate the relationship between the preoperative plasma concentration of fibrinogen and the postoperative bleeding volume and transfusions after cardiac surgery (study I).

II. To investigate if preoperative administration of fibrinogen concentrate to patients with low normal fibrinogen plasma concentration reduces bleeding and transfusion requirements after elective CABG (study II).

III. To investigate if administration of fibrinogen concentrate increases the risk of thromboembolic complications and death after cardiac surgery (study III).

IV. To investigate if in vitro fibrinogen supplementation combined with tranexamic acid has an additive pro coagulant effect compared to fibrinogen alone in blood samples from cardiac surgery patients (study IV). 


\section{PATIENTS AND METHODS}

\subsection{PATIENTS}

The four studies were approved by the Regional Ethics Committee and were conducted in accordance with the declaration of Helsinki. In study I and III, the committee waived patient consent due to the observational nature of the studies. In studies II and IV, patients were included after oral and written consent. Study II was approved by the Swedish Medical Products Agency and registered at clinicaltrials.gov (NCT00968045) prior to enrollment. The studies were all performed at the Department of Cardiothoracic Surgery at Sahlgrenska University Hospital, Gothenburg, Sweden. Patient characteristics in the four studies are displayed in Table 1.

\begin{tabular}{|c|c|c|c|c|}
\hline & $\begin{array}{c}\text { Study } \\
\text { I }\end{array}$ & $\begin{array}{l}\text { Study } \\
\text { II }\end{array}$ & $\begin{array}{c}\text { Study } \\
\text { III }\end{array}$ & $\begin{array}{c}\text { Study } \\
\text { IV }\end{array}$ \\
\hline $\mathbf{n}$ & 1954 & 48 & 5408 & 15 \\
\hline Age & $66 \pm 12$ & $64 \pm 8$ & $67 \pm 11$ & $65 \pm 4$ \\
\hline Female gender & $489(25 \%)$ & $1(2 \%)$ & $178(25 \%)$ & $1(7 \%)$ \\
\hline BMI, kg/m2 & $27 \pm 4$ & $27 \pm 3$ & $27 \pm 4$ & $28 \pm 4$ \\
\hline Smoking & $228(12 \%)$ & $20(4 \%)$ & - & $3(20 \%)$ \\
\hline Diabetes & $402(21 \%)$ & $7(15 \%)$ & $1074(20 \%)$ & $3(20 \%)$ \\
\hline EuroSCORE I & $5.1 \pm 3.0$ & $1.9 \pm 1.8$ & $5.3 \pm 3.1$ & - \\
\hline \multicolumn{5}{|l|}{ Platelet inhibition } \\
\hline DAPT & $636(33 \%)$ & $12(25 \%)$ & 2127 (39\%) & $\frac{1}{-}$ \\
\hline Fibrinogen g/L & $3.8 \pm 1.0$ & $3.0 \pm 0.4$ & $3.9 \pm 1.7$ & $3.3 \pm 05$ \\
\hline Platelet count $\times 10^{\wedge} 9$ & $260 \pm 78$ & $231 \pm 62$ & $251 \pm 77$ & $236 \pm 115$ \\
\hline Creatinine umol/L & $89 \pm 55$ & $81 \pm 12$ & $91 \pm 67$ & $93 \pm 4$ \\
\hline Hemoglobin $\mathrm{g} / \mathrm{L}$ & $137 \pm 15$ & $145 \pm 9$ & $137 \pm 15$ & $148 \pm 11$ \\
\hline CPB time, min & $95 \pm 42$ & $68 \pm 19$ & $90 \pm 38$ & $73 \pm 24$ \\
\hline Acute surgery & $88(5 \%)$ & - & $366(7 \%)$ & - \\
\hline \multicolumn{5}{|l|}{ Operative procedure } \\
\hline CABG & 1075 (55\%) & $48(100 \%)$ & 3069 (57\%) & $15(100 \%)$ \\
\hline Valve & $541(28 \%)$ & - & $1212(22 \%)$ & - \\
\hline CABG+Valve & $205(10 \%)$ & - & $651(12 \%)$ & - \\
\hline Other & $133(7 \%)$ & - & $476(9 \%)$ & - \\
\hline
\end{tabular}

Table 1. Patient characteristics in the four studies. Continuous data are shown as mean $\pm S D$, categorical data as number (\%). 


\subsection{METHODS}

\section{Clinical management}

CPB was performed in all patients. Anesthesia was induced with fentanyl, propolipid and rocuronium and maintained with sevoflurane in most cases. During CPB, anesthesia was maintained with propolipid. Before cannulation, heparin was given to keep activated clotting time (ACT) above $480 \mathrm{~s}$. After $\mathrm{CPB}$, protamine was administered to reverse the heparin effect reducing ACT to less than $130 \mathrm{~s}$. All patients received $2 \mathrm{~g}$ of tranexamic acid after induction of anesthesia and at the end of surgery.

The CPB circuit consisted of a hollow fibre membrane oxygenator and roller pumps with a standard non-pulsatile technique and hemodilution. The operations were performed in normothermia or mild hypothermia (bladder temperature $35-36^{\circ} \mathrm{C}$ ). Cardio protection was achieved with cold blood cardioplegia. Weaning of CPB was performed after re-warming to a bladder temperature of $36^{\circ} \mathrm{C}$. Preoperative aspirin (ASA) was not discontinued before surgery. Ticagrelor and clopidogrel were discontinued three and five days before surgery, respectively, in nonemergent cases.

The local transfusion protocol specified that RBCs should be transfused when hemoglobin $(\mathrm{Hb})$ was below 60-70 g/L or when a clinically significant anemia occurs. Plasma should be transfused in case of significant bleeding and a prolonged clotting time (CT) on thromboelastometry. Platelets should be transfused in case of significant bleeding and a known or suspected platelet dysfunction Sustained effect of heparin was tested with ROTEM $®$-HEPTEM or ACT and reversed with protamine. Fibrinogen was administered to patients with ongoing bleeding and signs of impaired fibrinogen function on ROTEM $®$-FIBTEM analysis. Overall, the final decision regarding transfusions and fibrinogen administration was left to the anestethist in charge.

Postoperative bleeding was defined as the total amount of chest tube drainage during the first 12 postoperative hours after closure of the sternum, or until re-exploration. A bleeding volume $>1000 \mathrm{ml}$ in 12 hours was defined as excessive bleeding. 


\section{Methods Study I}

At total of 2208 adult cardiac operations were performed at Sahlgrenska University Hospital from February 2009 to January 2011. After excluding 170 patients $(6.1 \%)$ due to missing data, a total of 1954 patients were included in the study. All elective and acute procedures were included: CABG, valve surgery, combined CABG and valve surgery, GUCH surgery, and arrhythmia operations, with an exception of surgical procedures on the ascending aorta. If a patient underwent more than one operation during one hospital admission only the first operation was included in the analysis. We sought to investigate the correlation between preoperative plasma fibrinogen concentration and bleeding and transfusion of RBC's respectively. The included patients were also arbitrarily divided into five groups according to their preoperative fibrinogen concentration $(\leq 2.5$, 2.6-3.0, 3.1-3.8, 3.9-4.5 and $\geq 4.6 \mathrm{~g} / \mathrm{L}$ ).

Blood samples were collected the day before surgery in elective cases or immediately before surgery in acute cases. Plasma fibrinogen concentration was determined according to the method by Clauss (5) with a reference value at the time of $2.0-4.5 \mathrm{~g} / \mathrm{L}$. Activated thromboplastin time (APTT), serum creatinine, $\mathrm{Hb}$, platelet count (PLT) and prothrombin time (PT) were measured preoperatively and analyzed with standard clinical methods. The total amount of RBC's, plasma and platelets during the hospital stay was recorded.

\section{Methods study II}

From April 2009 to February 2012, 52 patients were included in the study. Patients were eligible if they were scheduled for first time elective CABG and had a plasma fibrinogen concentration of $\leq 3.8 \mathrm{~g} / \mathrm{L}$. Predefined exclusion criteria were known liver- or kidney disease or known bleeding disorder. Low molecular weight heparin (LMWH) was discontinued the day before surgery. Clopidogrel and warfarin were withdrawn at least five days prior to surgery. Acetyl salicylic acid (ASA) was not discontinued. 


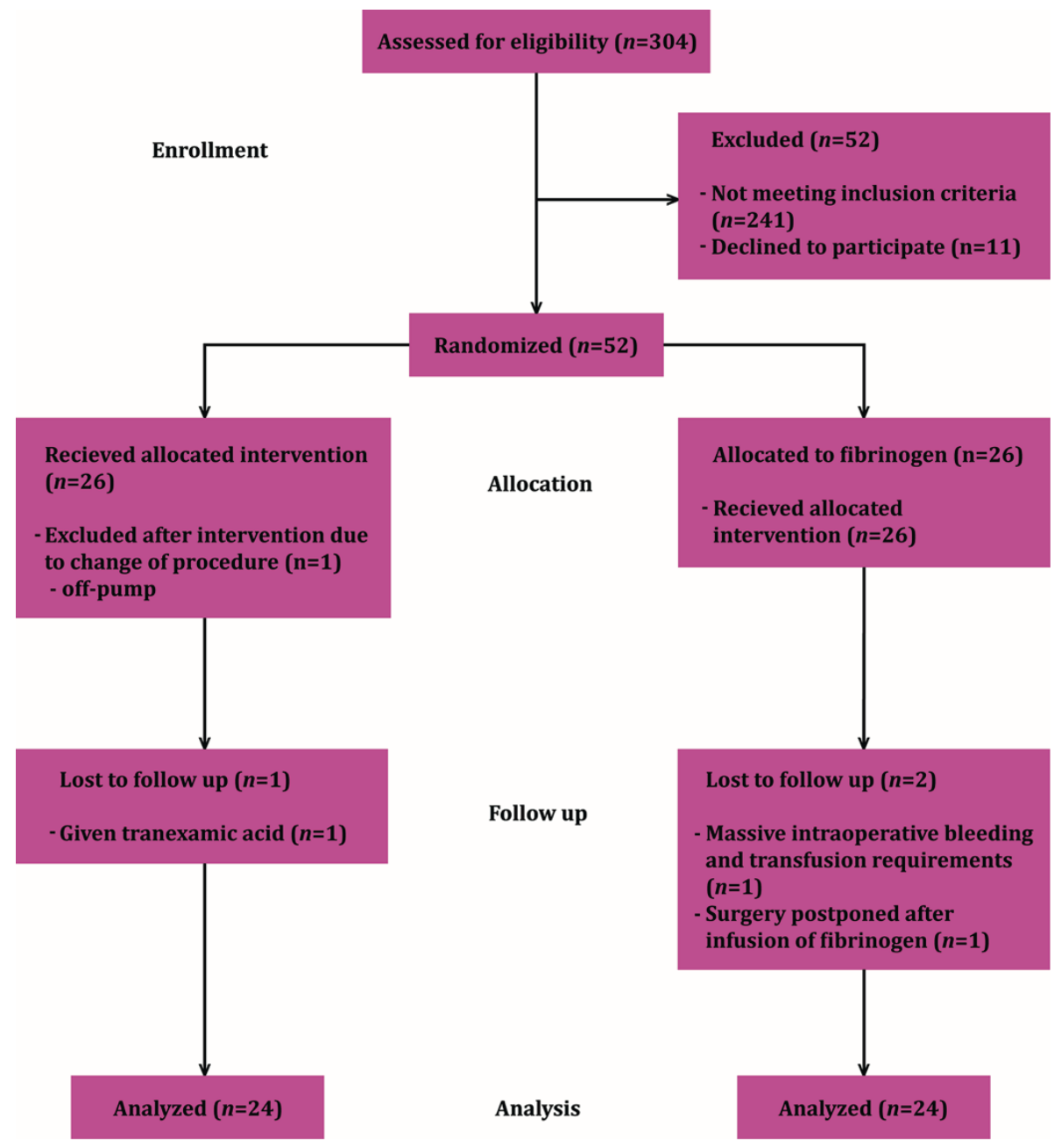

Figure 9. Flow chart for enrollment, allocation, follow up, and analysis.

Patients were randomized to receive either $2 \mathrm{~g}$ of fibrinogen concentrate (Haemocomplettan ${ }^{\circledR}$; CSL Behring, Marburg, Germany) or placebo, Figure 9. Bleeding during the first 12 postoperative hours was compared between the groups. Secondary endpoints were estimated intraoperative bleeding volume, total perioperative bleeding volume, total number of transfused allogenic blood products, proportion of transfused patients, hemoglobin concentrations two and twenty-four hours after CPB, plasma 
fibrinogen concentration, PLT, APTT, and PT before, during and after CPB. Preoperative blood samples were collected on the day before surgery.

Subjects were randomized using block randomization with six patients per group where three patients received the study drug and three patients received placebo. A blinded infusion of either the study drug or placebo, prepared by the hospital pharmacy, was administered after induction of anesthesia but before skin incision. Patients and staff were blinded regarding group allocation. The allocation list was not broken until completion of the study and after data analysis.

Plasma fibrinogen concentration was measured according to the method of Clauss with a reference interval of 2.0-4.5 g/L. Hb, PLT ,PT, APTT and serum creatinine level were measured with standard clinical methods. Thromboelastometry was not used routinely, but was utilized in case of bleeding. Fibrinogen was administered outside the study protocol to patients with ongoing bleeding and a ROTEM ${ }^{\circledR}$-FIBTEM analysis result of less than $10 \mathrm{~mm}$.

\section{Methods Study III}

All patients who underwent first-time cardiac surgery at our department between 2009 and 2014 were included in a retrospective observational study. All types of cardiac surgery were included: CABG, valve surgery, combined CABG- and valve surgery, GUCH surgery and arrhythmia operations. Patients who underwent surgery on the ascending aorta, and re-sternotomies were excluded. In total, 6442 patients were assessed for inclusion, and 5408 were included, Figure 10. 


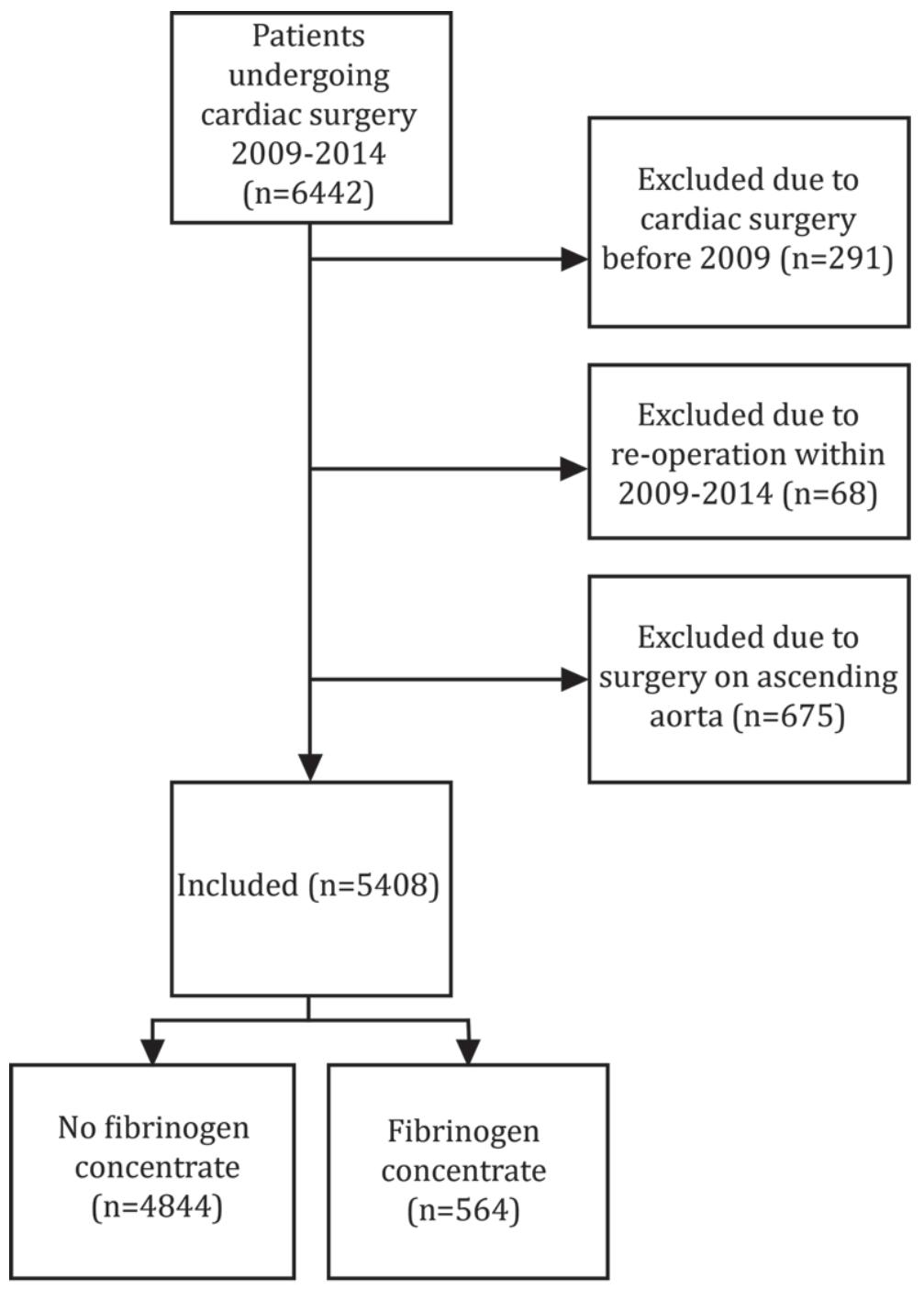

Figure 10. Patients assessed for inclusion in study III.

Patient characteristics, type of surgery, pre- and postoperative laboratory testing, bleeding volume, number of transfusions and fibrinogen administration were retrospectively collected from patient records and the Swedish Heart Surgery Registry (110). The National Patient Registry (NPR) and the Cause of Death Registry supplied data on thromboembolic complications and death $(111,112)$. The merging of data was possible by using the social security number given to each Swedish citizen. 
The incidence of a composite of thromboembolic events and mortality at one year after surgery were compared between patients who received perioperative fibrinogen concentrate and patients who did not. Secondary endpoints were the incidence of the composite endpoint at 30 days and mortality at 30 days and 1 year respectively.

\begin{tabular}{lc} 
Diagnosis & ICD code \\
\hline Myocardial infarction & I21 \\
Revascularization & FN \\
Ischaemic stroke & I63 \\
Mesenterial ischemia & K55 \\
Peripheral arterial embolization & I74 \\
Pulmonary embolization & I26 \\
Deep vein thrombosis & I80 \\
Portal vein thrombosis & I81.9 \\
\hline
\end{tabular}

Table 2. ICD-codes in the composite endpoint.

\section{Methods Study IV}

Fifteen patients scheduled for first-time elective CABG between November 2017 to January 2018 and a plasma fibrinogen concentration within the normal range (1.8-3.8 g/L) were included. At the time of this study, the hospital implemented a new reference interval for plasma fibrinogen concentration due to both a new instrument and a new reagent. All included patients were preoperatively treated with ASA which was not discontinued before surgery. Exclusion criteria were known bleeding disorder, renal disease, and on-going treatment with platelet inhibiting agents and anti-coagulant agents that was not discontinued according to institutional practice.

In accordance with our institutional protocol, two grams of TXA was administered after induction of anesthesia, but before surgical incision, and at the end of surgery. Blood samples for clot formation analyses were 
collected before and five minutes after both TXA doses. Samples for platelet count, hemoglobin and plasma fibrinogen concentration analyses were collected the day before surgery and immediately prior to the second dose of TXA.

For each subject, two portions at each sample occasion were prepared for ROTEM $^{\circledR}$-FIBTEM analysis, giving a total of eight samples, presented in Figure 11 and 12 . All samples collected before surgery were diluted with Ringer's Acetate to achieve a hemodilution of $21 \%$ in order to mimic hemodilution during CPB. After dilution, fibrinogen concentrate was added in a dose corresponding to $3 \mathrm{~g}$ fibrinogen given to a $70 \mathrm{~kg}$ patient.
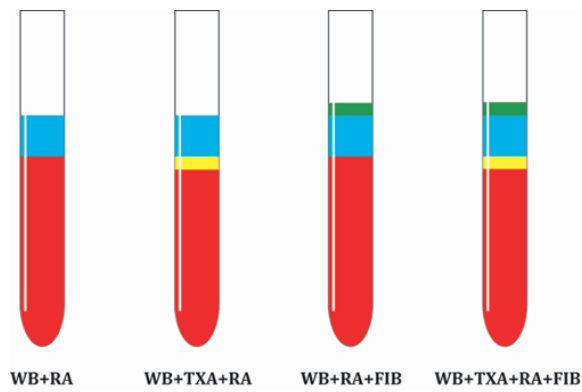

Figure 11. Preoperative samples prepared for thromboelastometry. Baseline sample contains blood diluted with Ringer's Acetate. $W B=$ whole blood(red); $R A=$ Ringers Acetate (blue); TXA=tranexamic acid (yellow); FIB=fibrinogen (green)

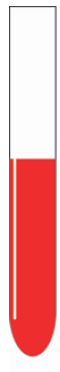

WB

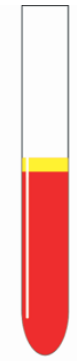

WB+TXA

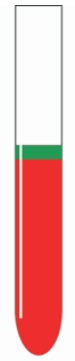

WB+FIB

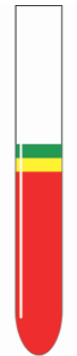

WB+TXA+FIB

Figure 12. Postoperative samples prepared for thromboelastometry. WB=whole blood(red); TXA=tranexamic acid(yellow); FIB=fibrinogen(green)

The clot formation process was assessed with thromboelastometry $\left(\right.$ ROTEM $\left.^{\circledR}\right)$. ROTEM ${ }^{\circledR}$-FIBTEM in which clot formation is activated by tissue factor was used. Changes in clotting time CT), maximum clot firmness (MCF) and clot lysis (ML) were compared between the samples. 


\subsection{STATISTICAL ANALYSES}

For all studies, data are presented as mean with standard deviation (SD), median with interquartile range (IQR) or proportions with percentage (\%) as described. Any p-value $<0.05$ was considered statistically significant.

\section{Study I}

Categorical variables were compared between the groups with $\chi 2$-test and continuous variables with one way analysis of variance (ANOVA). The importance of fibrinogen concentration for postoperative bleeding and transfusion were analyzed by handling the explanatory and the outcome variable as continuous variables by univariate testing and multiple models with fibrinogen as a continuous variable and bleeding as a dichotomous variable $(<1000 \mathrm{ml} / 12 \mathrm{~h}$ and $>1000 \mathrm{ml} / 12 \mathrm{~h})$. Bleeding and transfusions of RBCs were also compared between the subgroups according to preoperative plasma concentration of fibrinogen.

To explore risk factors for bleeding $>1000 \mathrm{ml}$ in 12 hours and transfusions, univariate and multivariable logistic regression was performed and presented as odds ratios (OR) with 95\% confidence intervals (CI). All factors univariately associated with bleeding or transfusion were used in the multivariable models.

\section{Study II}

Normality of distribution was tested with Shapiro-Wilk test. Group comparisons in normally distributed continuous data were made with the Student's t-test and in non-normally distributed data with the MannWhitney U-test. The $\chi 2$-test was used to compare categorical data. For group comparisons of variables analyzed at more than one occasion, ANOVA for repeated measurements was used, followed by the Students ttest if ANOVA indicated a difference. Changes from baseline within a group were analyzed with a paired t-test.

A power calculation, based on the previously described pilot study was made (105). To show a 30\% reduction in bleeding volume in the treatment group, 25 patients were needed in each group with $80 \%$ power and a significance level of 0.05 . 


\section{Study III}

Categorical variables were compared between the groups with the $\chi 2$-test or Fisher's test if small numbers. Continuous variables were compared between the groups with the t-test or the Mann-Whitney test depending on variable distribution. To assess the importance of fibrinogen concentrate administration for the composite event and mortality at 30 days postoperatively, univariate and multivariable logistic regression analyses was used. To assess the importance of fibrinogen concentrate administration for survival time and time to the composite event up to one year, univariate and multivariable Cox regression analyses were used. The variables that were statistically significant in the univariate model were included in the multivariable logistic regression model and in the Cox regression model. Two propensity score-based sensitivity analyses were performed, based on the probability of administration of fibrinogen concentrate.

\section{Study IV}

To be able to detect a $20 \%(2 \mathrm{~mm})$ change in FIBTEM-MCF with a standard deviation of $2.5 \mathrm{~mm}, 80 \%$ power and a significance level of $0.05,12$ patients were needed. To achieve marginal, 15 patients were included. The non-parametric Wilcoxon signed paired test was used to compare results from baseline and after addition of TXA, fibrinogen and TXA plus fibrinogen, respectively. 


\section{RESULTS}

\section{1 PREOPERATIVE PLASMA CONCENTRATION OF FIBRINOGEN, BLEEDING AND TRANSFUSIONS (I)}

The mean plasma fibrinogen concentration in the cohort was $3.8 \pm 1.0 \mathrm{~g} / \mathrm{L}$. Eight patients $(0.41 \%)$ had a fibrinogen concentration below the normal reference limit $(2.0 \mathrm{~g} / \mathrm{L})$ and 370 patients $(17 \%)$ had a concentration above the normal reference limit $(4.5 \mathrm{~g} / \mathrm{L})$. Table 3 illustrates patient characteristics in relation to preoperative fibrinogen concentration.

\begin{tabular}{lccccc} 
& \multicolumn{5}{c}{ Fibrinogen Concentration, $\mathrm{g} / \mathrm{L}$} \\
\cline { 2 - 6 } Variable & $\leq 2.5(\mathrm{n}=105)$ & $2.6-3.0(\mathrm{n}=340)$ & $3.1-3.8(\mathrm{n}=729)$ & $3.9-4.5(\mathrm{n}=410)$ & $\geq 4.6(\mathrm{n}=370)$ \\
\hline Age, $\mathrm{y}$ & $57 \pm 18$ & $63 \pm 13$ & $67 \pm 11$ & $68 \pm 10$ & $67 \pm 11$ \\
Female gender & $16(15)$ & $69(20)$ & $169(23)$ & $130(32)$ & $106(29)$ \\
BMI, kg/m ${ }^{2}$ & $25 \pm 4$ & $23 \pm 3$ & $27 \pm 4$ & $28 \pm 4$ & $28 \pm 5$ \\
Weight, kg & $76 \pm 13$ & $79 \pm 13$ & $82 \pm 14$ & $82 \pm 14$ & $83 \pm 17$ \\
CABG & $29(28)$ & $158(46)$ & $418(57)$ & $238(58)$ & $232(63)$ \\
Diabetes & $9(8.7)$ & $46(14)$ & $149(20)$ & $101(25)$ & $97(27)$ \\
CPB time, min & $101 \pm 48$ & $95 \pm 45$ & $94 \pm 40$ & $96 \pm 43$ & $95 \pm 40$ \\
Smoking & $4(4)$ & $26(8)$ & $81(11)$ & $60(15)$ & $61(17)$ \\
Acute operation & $5(5)$ & $9(3)$ & $27(4)$ & $15(4)$ & $32(9)$ \\
Aspirin & $43(41)$ & $211(62)$ & $529(73)$ & $300(73)$ & $279(75)$ \\
Clopidogrel $(<5$ days pre-op) & $5(5)$ & $24(7)$ & $58(8)$ & $38(9)$ & $58(16)$ \\
APTT, $s$ & $38 \pm 19$ & $36 \pm 10$ & $36 \pm 6$ & $36 \pm 5$ & $37 \pm 11$ \\
PT (INR) & $1.12 \pm 0.20$ & $1.09 \pm 0.19$ & $1.11 \pm 0.28$ & $1.12 \pm 0.30$ & $1.11 \pm 0.32$ \\
Platelet count, $\times 10^{9} / \mathrm{L}$ & $235 \pm 74$ & $236 \pm 63$ & $253 \pm 65$ & $270 \pm 78$ & $295 \pm 99$ \\
Serum creatinine, $\mu$ mol/L & $83 \pm 20$ & $83 \pm 20$ & $87 \pm 34$ & $91 \pm 55$ & $99 \pm 72$ \\
eGFR, mL/min & $95 \pm 33$ & $91 \pm 30$ & $89 \pm 31$ & $85 \pm 31$ & $84 \pm 33$ \\
Hemoglobin, g/L & $143 \pm 12$ & $141 \pm 13$ & $138 \pm 14$ & $137 \pm 14$ & $129 \pm 16$ \\
\hline
\end{tabular}

Table 3. Patient characteristics in relation to preoperative fibrinogen concentration. Continuous data are shown as mean $\pm S D$, categorical data as number (\%).

\section{Bleeding}

The mean bleeding volume was $563 \pm 374 \mathrm{ml} / 12$ hours and 96 patients (4.9\%) underwent re-exploration due to excessive bleeding or tamponade. Ten percent of the patients had a postoperative bleeding volume of more than $1000 \mathrm{ml} / 12$ hours. There was a weak inverse correlation between preoperative fibrinogen concentration and postoperative bleeding volume $(\mathrm{r}=-0.17, \mathrm{p}<0.001)$. Patient characteristics and univariate risk factors for bleeding $>1000 \mathrm{ml} / 12$ hours are presented 
in Table 4. Independent risk factors for excessive bleeding were low fibrinogen concentration, low BMI, longer CPB time, clopidogrel intake $<5$ days before surgery, low preoperative platelet count and acute operation.

\begin{tabular}{|c|c|c|c|c|}
\hline \multirow[b]{2}{*}{ Variable } & \multicolumn{2}{|c|}{ Bleeding, $\mathrm{mL} / 12$ Hours } & \multirow[b]{2}{*}{ OR $(95 \% \mathrm{CI})$} & \multirow[b]{2}{*}{$p$ Value } \\
\hline & $\leq 1,000(\mathrm{n}=1,749)$ & $>1,000(\mathrm{n}=205)$ & & \\
\hline Age, $y$ & $66 \pm 12$ & $67 \pm 12$ & $1.00(0.99-10.2)$ & 0.33 \\
\hline Female gender & $450(26)$ & 39 (19) & $0.67(0.47-0.98)$ & 0.037 \\
\hline BMI, $\mathrm{kg} / \mathrm{m}^{2}$ & $27.1 \pm 4.3$ & $25.6 \pm 4.0$ & $0.91(0.88-0.95)$ & $<0.001$ \\
\hline Smoking & $204(12)$ & $24(12)$ & $1.02(0.65-1.59)$ & 0.95 \\
\hline Diabetes & $365(21)$ & $37(18)$ & $0.84(0.58-1.23)$ & 0.38 \\
\hline \multicolumn{5}{|l|}{ Pre-op medication } \\
\hline Aspirin & $1,220(70)$ & $142(69)$ & $0.97(0.71-1.33)$ & 0.87 \\
\hline Clopidogrel $<5$ days pre-op & $156(9)$ & $27(13)$ & 1.55 (1.001-2.39) & 0.0496 \\
\hline \multicolumn{5}{|l|}{ Pre-op analyses } \\
\hline Fibrinogen, g/L & $3.8 \pm 1.0$ & $3.6 \pm 1.0$ & $0.75(0.64-0.89)$ & 0.001 \\
\hline aPTT, s & $36.1 \pm 9.1$ & $36.5 \pm 5.2$ & $1.00(0.99-1.02)$ & 0.47 \\
\hline PT (INR) & $1.1 \pm 0.3$ & $1.1 \pm 0.2$ & $1.04(0.63-1.74)$ & 0.87 \\
\hline Platelet count, $\times 10^{9} / \mathrm{L}$ & $262 \pm 77$ & $245 \pm 88$ & $0.997(0.995-0.999)$ & 0.004 \\
\hline $\mathrm{eGFR}, \mathrm{mL} / \mathrm{min}$ & $88 \pm 31$ & $84 \pm 32$ & $0.996(0.99-1.001)$ & 0.092 \\
\hline Hemoglobin, g/L & $137 \pm 15$ & $136 \pm 15$ & $0.99(0.98-1.01)$ & 0.52 \\
\hline CABG & $980(56)$ & $95(46)$ & $0.68(0.51-0.91)$ & 0.009 \\
\hline Acute operation & $71(4)$ & $17(8)$ & $2.14(1.23-3.70)$ & 0.007 \\
\hline ECC time, $\min$ & $94 \pm 41$ & $110 \pm 53$ & $1.01(1.004-1.010)$ & $<0.001$ \\
\hline
\end{tabular}

Table 4. Univariate risk factors for bleeding $\leq 1000 \mathrm{ml}$ or $>1000 \mathrm{ml} /$ Hours ( $\mathrm{n}=1954$ ). Continuous data are shown as mean $\pm S D$, categorical data as number (\%).

When dividing patients into subgroups according to their preoperative fibrinogen concentration, the patients with the lower fibrinogen levels had both a higher postoperative mean bleeding volume and a higher percentage of excessive bleeding. Re-operation for bleeding was more common in patients with the highest and the lowest fibrinogen levels, illustrated in Figure 13. In multivariable analysis, patients with the lowest fibrinogen concentration still had a significant increased risk of bleeding $>1000 \mathrm{ml} / 12$ hours compared to patients with the highest levels, presented in Table 5. 

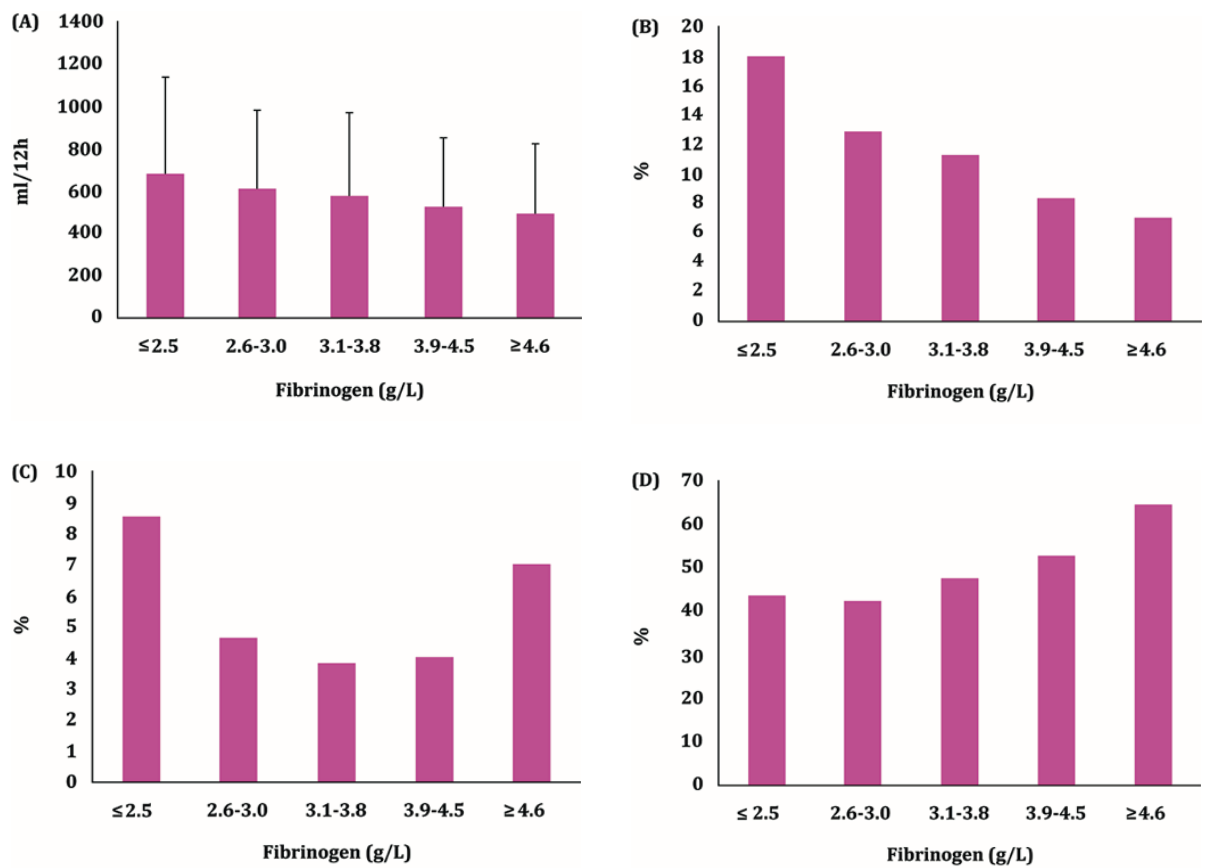

Figure 13. (A)Unadjusted mean postoperative blood loss, (B) blood loss exceeding $1000 \mathrm{ml} / 12 \mathrm{~h}(\mathrm{C})$ re-exploration rate (D) proportions of patients receiving $R B C$ in patients with different fibrinogen concentrations. Error bars indicate $S D$. 


\begin{tabular}{lllll}
$\begin{array}{l}\text { Fibrinogen } \\
(\mathrm{g} / \mathrm{L})\end{array}$ & $\begin{array}{c}\text { Univariate OR } \\
(95 \% \mathrm{CI})\end{array}$ & $\begin{array}{c}p \\
\text { Value }\end{array}$ & $\begin{array}{c}\text { Multiple } \\
\text { Model OR } \\
(95 \% \mathrm{CI})\end{array}$ & $\begin{array}{c}p \\
\text { Value }\end{array}$ \\
\hline$\leq 2.5$ & $2.92(1.55-5.53)$ & 0.001 & $2.31(1.16-4.59)$ & 0.017 \\
$2.6-3.0$ & $1.97(1.18-3.27)$ & 0.009 & $1.64(0.95-2.83)$ & 0.074 \\
$3.1-3.8$ & $1.68(1.06-2.66)$ & 0.028 & $1.55(0.96-2.5)$ & 0.075 \\
$3.9-4.5$ & $1.20(0.70-2.03)$ & 0.51 & $1.17(0.68-2.03)$ & 0.57 \\
$\geq 4.6$ & 1 & - & 1 & - \\
\hline
\end{tabular}

$\mathrm{CI}=$ confidence interval; $\quad \mathrm{OR}=$ odds ratio

Table 5. Unadjusted and adjusted Odds Ratios (OR) for bleeding over $1000 \mathrm{ml} / 12 \mathrm{~h}$ in subgroups with different fibrinogen concentrations.

\section{Transfusions}

There was a weak correlation between preoperative fibrinogen concentration and the number of $\mathrm{RBC}$ transfusions $(\mathrm{r}=0.14, \mathrm{p}=<0.001)$.

Patient characteristics and univariate risk factors for RBC transfusion are presented in Table 6. In the multivariable analysis, low fibrinogen levels were not associated with an increased risk of RBC transfusion (OR 1.10; 95\% CI 0.89-1.28 per $\mathrm{g} / \mathrm{L}, \mathrm{p}=0.49$ ). Independent factors associated with $\mathrm{RBC}$ transfusion were acute operation, impaired renal function, long CPBtime, clopidogrel intake $<5$ days before surgery and low preoperative hemoglobin concentration. Within the fibrinogen concentration subgroups, there was no significant difference in risk of transfusion of RBC and fibrinogen concentration in the multivariable analysis. 


\begin{tabular}{|c|c|c|c|c|}
\hline Variable & $\begin{array}{l}\text { No Red Cell Transfusion } \\
\qquad(\mathrm{n}=964)\end{array}$ & $\begin{array}{l}\text { Red Cell Transfusion } \\
\qquad(\mathrm{n}=990)\end{array}$ & OR $(95 \% \mathrm{Cl})$ & $p$ Value \\
\hline Age, y & $64 \pm 12$ & $68 \pm 11$ & $1.03(1.02-1.04)$ & $<0.001$ \\
\hline Female gender & $158(16)$ & $331(33)$ & $2.57(2.06-3.18)$ & $<0.001$ \\
\hline BMI, $\mathrm{kg} / \mathrm{m}^{2}$ & $27.4 \pm 4$ & $26.5 \pm 4$ & $0.95(0.93-0.97)$ & $<0.001$ \\
\hline Smoking & $106(11)$ & $124(13)$ & $1.19(0.90-1.57)$ & 0.223 \\
\hline Diabetes & $183(19)$ & $219(22)$ & $1.22(0.98-1.52)$ & 0.073 \\
\hline \multicolumn{5}{|l|}{ Pre-op medication } \\
\hline Aspirin & $682(71)$ & $680(69)$ & $0.91(0.75-1.11)$ & 0.36 \\
\hline Clopidogrel $<5$ days pre-op & $58(6)$ & $125(13)$ & $2.26(1.63-3.12)$ & $<0.001$ \\
\hline \multicolumn{5}{|l|}{ Pre-op analyses } \\
\hline Fibrinogen, g/L & $3.7 \pm 0.9$ & $4.0 \pm 1.1$ & $1.36(1.24-1.49)$ & $<0.001$ \\
\hline aPTT, s & $36 \pm 8$ & $37 \pm 10$ & $1.02(1.00-1.03)$ & 0.007 \\
\hline PT (INR) & $1.1 \pm 0.2$ & $1.1 \pm 0.3$ & $1.64(1.15-2.34)$ & 0.006 \\
\hline Platelet count, $\times 10^{9} / \mathrm{L}$ & $257 \pm 70$ & $263 \pm 85$ & $1.001(1.000-1.002)$ & 0.095 \\
\hline $\mathrm{eGFR}, \mathrm{mL} / \mathrm{min}$ & $96 \pm 31$ & $80 \pm 30$ & $0,98(0.97-0.99)$ & $<0.001$ \\
\hline Hemoglobin, g/L & $143 \pm 12$ & $131 \pm 15$ & $0.94(0.93-0.95)$ & $<0.001$ \\
\hline CABG & $599(62)$ & $476(48)$ & $0.56(0.47-0.68)$ & $<0.001$ \\
\hline Acute operation & $24(2.5)$ & $64(6.5)$ & $2.71(1.68-4.36)$ & $<0.001$ \\
\hline CPB time, $\min$ & $84 \pm 31$ & $106 \pm 48$ & $1.015(1.012-1.018)$ & $<0.001$ \\
\hline
\end{tabular}

Table 6. Univariate risk factors for RBC transfusion ( $n=1954)$. Continuous data are shown as mean $\pm S D$, categorical data as number (\%).

\subsection{PROPHYLACTIC TREATMENT WITH FIBRINOGEN CONCENTRATE (II)}

Mean preoperative plasma fibrinogen concentration was $3.0 \pm 0.4 \mathrm{~g} / \mathrm{L}$ in the treatment group and $3.0 \pm 0.4$ in the placebo group $(\mathrm{p}=0.81)$. Infusion of fibrinogen concentrate increased plasma fibrinogen concentration by $0.2 \pm 0.4 \mathrm{~g} / \mathrm{L}$ and infusion of placebo decreased the concentration by $0.2 \pm 0.4 \mathrm{~g} / \mathrm{L}$ ( $\mathrm{p}=0.004$ between the groups).

There was no significant difference between the groups in median postoperative bleeding within 12 hours, nor in any other bleeding estimates or transfusions. Five patients in each group bled more than $1000 \mathrm{ml}$. Variables of postoperative bleeding and transfusions are displayed in Figure 14 and Table 7. Changes of fibrinogen concentration over time are presented in Figure 15. 


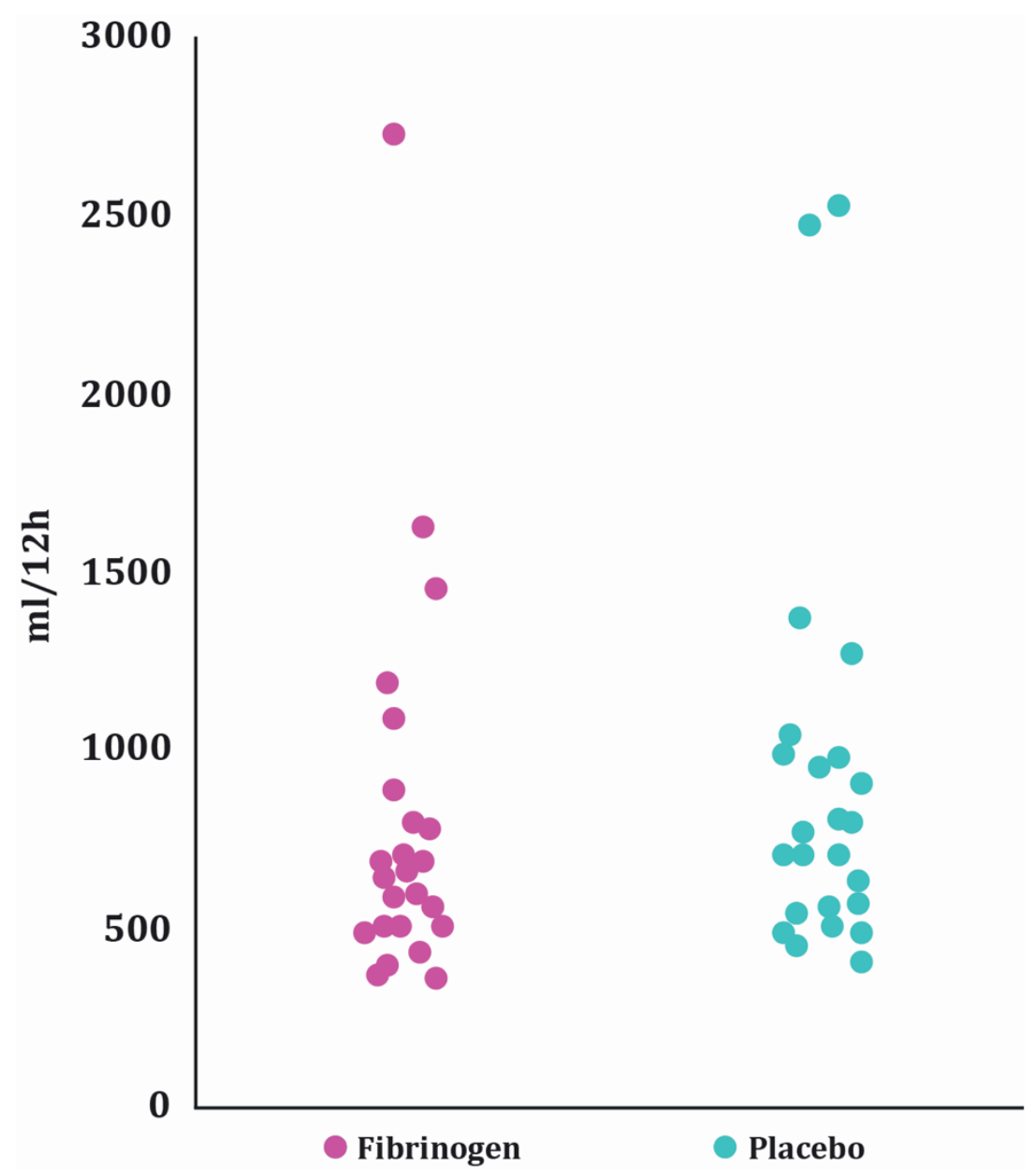

Figure 14. Postoperative bleeding volume in individual subjects. There was no significant difference in median bleeding volume between the groups $(p=0.29)$. 


\section{Fibrinogen $(n=24) \quad$ Placebo $(n=24) \quad$ p-value}

Total bleeding 12 hours

\begin{tabular}{lccc}
\hline Mean & $1103(518)$ & $1272(588)$ & 0.30 \\
Median & $913(815-1230$ & $1185(930-1398)$ & 0.18 \\
Re-operation for bleeding & $1(4.2 \%)$ & $2(8.4 \%)$ & 0.55 \\
RBC transfusion & & & \\
Number of patients & $6(25.0 \%)$ & $6(25.0 \%)$ & 1.00 \\
Mean (units) & $0.63(1.17)$ & $1.33(3.11)$ & 0.30 \\
Median (units) & $0(0-1)$ & $0(0-1)$ & 0.88 \\
Fibrinogen (number) & $3(12 \%)$ & $7(29 \%)$ & 0.55 \\
\hline
\end{tabular}

Table 7. Bleeding and transfusions. Continuous data are shown as mean $\pm S D$ and median (25th and $75^{\text {th }}$ percentiles), categorical data as number (\%).

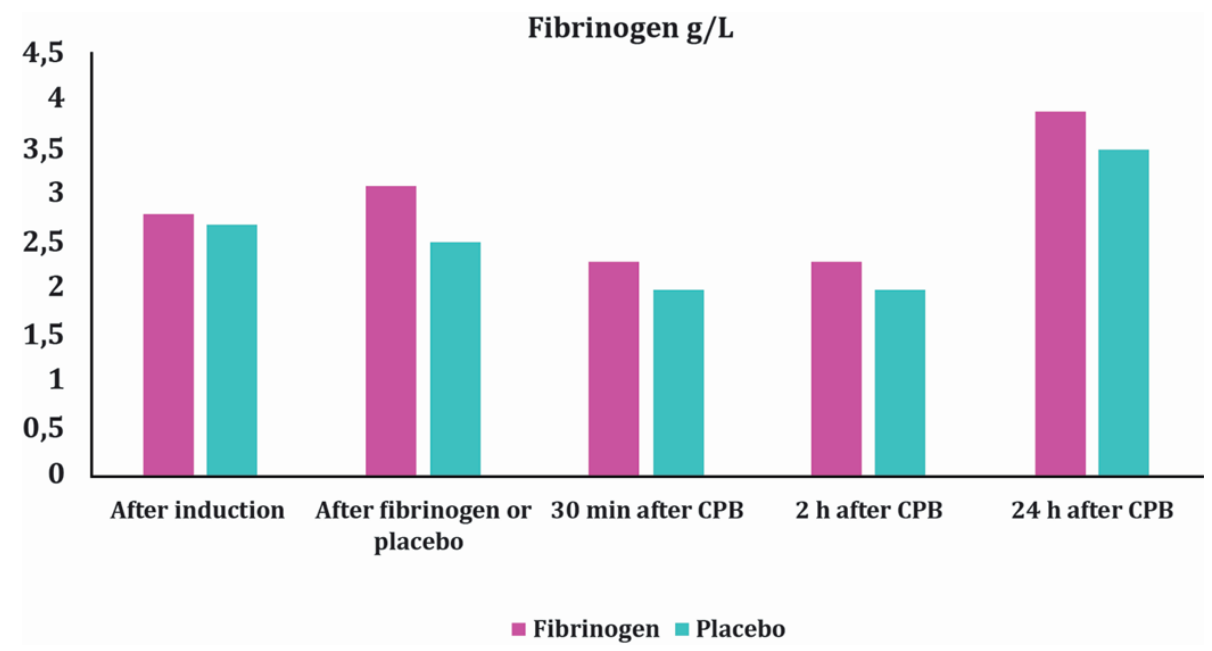

Figure 15. Changes in fibrinogen concentration $(g / L)$ over time.

Aortic clamp time and CPB time were significantly longer and preoperative $\mathrm{Hb}$ and Hct were significantly higher in the treatment group than in the placebo group. There were no clinically detectable side effects 
of fibrinogen infusion. One patient in the placebo group had signs of postoperative ischemia and heart failure where angiography revealed an occluded vein graft. Fibrinogen concentrate was administered postoperatively outside the study protocol to three patients in the treatment group and to seven in the placebo group.

\subsection{FIBRINOGEN ADMINISTRATION AND RISK OF THROMBOEMBOLIC COMPLICATIONS (III)}

Patient characteristics, divided into patients who received fibrinogen concentrate and patients who did not, are displayed in Table 8.

\section{One year outcome}

After one year, nearly $10 \%$ of the included patients had had at least one event included in the composite endpoint and the mortality rate was $4.8 \%$, Table 9. The patients who did receive fibrinogen concentrate did not have a higher risk for thromboembolic complications or death after adjustment for covariates, Table 10, Figure 16. 


\begin{tabular}{lccc} 
Variable & $\begin{array}{c}\text { Fibrinogen } \\
(\mathrm{n}=564)\end{array}$ & $\begin{array}{c}\text { No fibrinogen } \\
(\mathrm{n}=4844)\end{array}$ & $p$ Value \\
\hline Male sex & $438(78 \%)$ & $3592(74 \%)$ & 0.074 \\
Age, years & $68 \pm 11$ & $67 \pm 11$ & 0.14 \\
Body mass index & $26 \pm 4$ & $27 \pm 4$ & $<0.001$ \\
Pre-op fibrinogen concentration, g/L & $3.2(2.8-3.8)$ & $3.7(3.2-4.4)$ & $<0.001$ \\
Pre-op hemoglobin, g/L & $138 \pm 15$ & $136 \pm 15$ & 0.005 \\
Pre-op platelet count, $\times 10^{9} / \mathrm{L}$ & $234 \pm 71$ & $253 \pm 77$ & $<0.001$ \\
Pre-op prothrombin time, INR & $1.1(1.0-1.2)$ & $1.0(1.0-1.1)$ & $<0.001$ \\
Pre-op serum-creatinine, $\mu$ mol/L & $85(74-98.0)$ & $84.0(72-98)$ & 0.015 \\
Left ventricular ejection fraction $>50 \%$ & $398(71 \%)$ & $3494(72 \%)$ & 0.25 \\
Pre-op ASA treatment & $391(73 \%)$ & $3516(76 \%)$ & 0.29 \\
Pre-op dual antiplatelet therapy & $240(43 \%)$ & $1887(39 \%)$ & 0.098 \\
Hypertension & $273(48 \%)$ & $2531(52 \%)$ & 0.084 \\
Atrial fibrillation & $75(13 \%)$ & $728(15 \%)$ & 0.27 \\
Previous myocardial infarction & $147(26 \%)$ & $1360(28 \%)$ & 0.31 \\
Previous stroke & $43(8 \%)$ & $294(6 \%)$ & 0.15 \\
Diabetes & $130(24 \%)$ & $944(20 \%)$ & 0.037 \\
EuroSCORE I & $6(3-8)$ & $5(3-7)$ & $<0.001$ \\
CPB time, min & $88(69-128)$ & $81(64-107)$ & $<0.001$ \\
Surgical procedures & & & $<0.001$ \\
Valve surgery & $130(23 \%)$ & $1082(22 \%)$ & \\
CABG & $273(48 \%)$ & $2796(58 \%)$ & \\
CABG+Valve & $114(20 \%)$ & $537(11 \%)$ & \\
Other & $47(9 \%)$ & $429(9 \%)$ & \\
\hline
\end{tabular}

Table 8. Patient characteristics, divided into patients who received fibrinogen concentrate and those who did not. Continuous data are shown as mean $\pm S D$ and median (25th and $75^{\text {th }}$ percentiles), categorical data as number (\%). 


\begin{tabular}{lccc} 
& $\begin{array}{c}\text { No fibrinogen } \\
(\mathrm{n}=4844)\end{array}$ & $\begin{array}{c}\text { Fibrinogen } \\
(\mathrm{n}=564)\end{array}$ & $p$ Value \\
\hline Composite endpoint & $480(9.9 \%)$ & $85(15 \%)$ & $<0.001$ \\
thromboembolic events or & & & \\
mortality or new & & & \\
revascularization or myocardial & & & \\
infarction) & & & \\
Mortality & $200(4.1 \%)$ & $58(10 \%)$ & $<0.001$ \\
All thromboembolic events & $120(2.5 \%)$ & $17(3.0 \%)$ & 0.44 \\
New revascularization & $78(1.6 \%)$ & $4(0.7 \%)$ & 0.10 \\
Myocordial infarction & $93(1.9 \%)$ & $11(1.9 \%)$ & 0.87 \\
Ischaemic stroke & $95(2.0 \%)$ & $9(1.6 \%)$ & 0.55 \\
Deep vein thrombosis & $4(0.1 \%)$ & 0 & - \\
Pulmonary embolism & $13(0.3 \%)$ & $7(1.2 \%)$ & $<0.001$ \\
Mesenterial ischaemia & $4(0.1 \%)$ & 0 & - \\
Peripheral arterial embolism & $4(0.1 \%)$ & $1(0.2 \%)$ & 0.42 \\
Thrombosis of the portal vein & 1 & 0 & - \\
\hline
\end{tabular}

Table 9. Unadjusted outcome variables at one year after surgery in patients who did and did not receive fibrinogen concentrate perioperatively.

\begin{tabular}{lcccl} 
End point & $\begin{array}{c}\text { No fibrinogen } \\
(\mathrm{n}=4844)\end{array}$ & $\begin{array}{c}\text { Fibrinogen } \\
(\mathrm{n}=564)\end{array}$ & HR with 95\% CI & $p$ Value \\
\hline \multirow{2}{*}{ Composite endpoint $^{\mathrm{a}}$} & $\mathrm{n}(\%)$ & $\mathrm{n}(\%)$ & & \\
& $480(10 \%)$ & $85(15 \%)$ & $1.56(1.24-1.97)^{\mathrm{b}}$ & $<0.001$ \\
Mortality & & $1.11(0.84-1.46)^{\mathrm{c}}$ & 0.45 \\
& $200(4 \%)$ & $58(10 \%)$ & $2.58(1.93-3.46)^{\mathrm{d}}$ & $<0.001$ \\
& & & $1.38(0.93-2.04)^{\mathrm{e}}$ & 0.11 \\
\hline
\end{tabular}

Table 10. Association between fibrinogen concentrate administration and composite endpoint and mortality during the first year after surgery. Hazard ratios (HR) based on Cox regression models are presented. ${ }^{a}$ composite endpoint ${ }^{b}$ unadjusted $H R{ }^{c}$ adjusted $H R$ adjusted for age, sex, BMI, diabetes, preoperative antiplatelet therapy, plasma fibrinogen concentration, $\mathrm{Hb}$, PLT count, preoperative serum-creatinine, PT, history of ischemic stroke, EuroSCORE I, CPB time, surgical procedure and total perioperative transfusions ${ }^{d}$ unadjusted HR, HR adjusted for see $c$. 


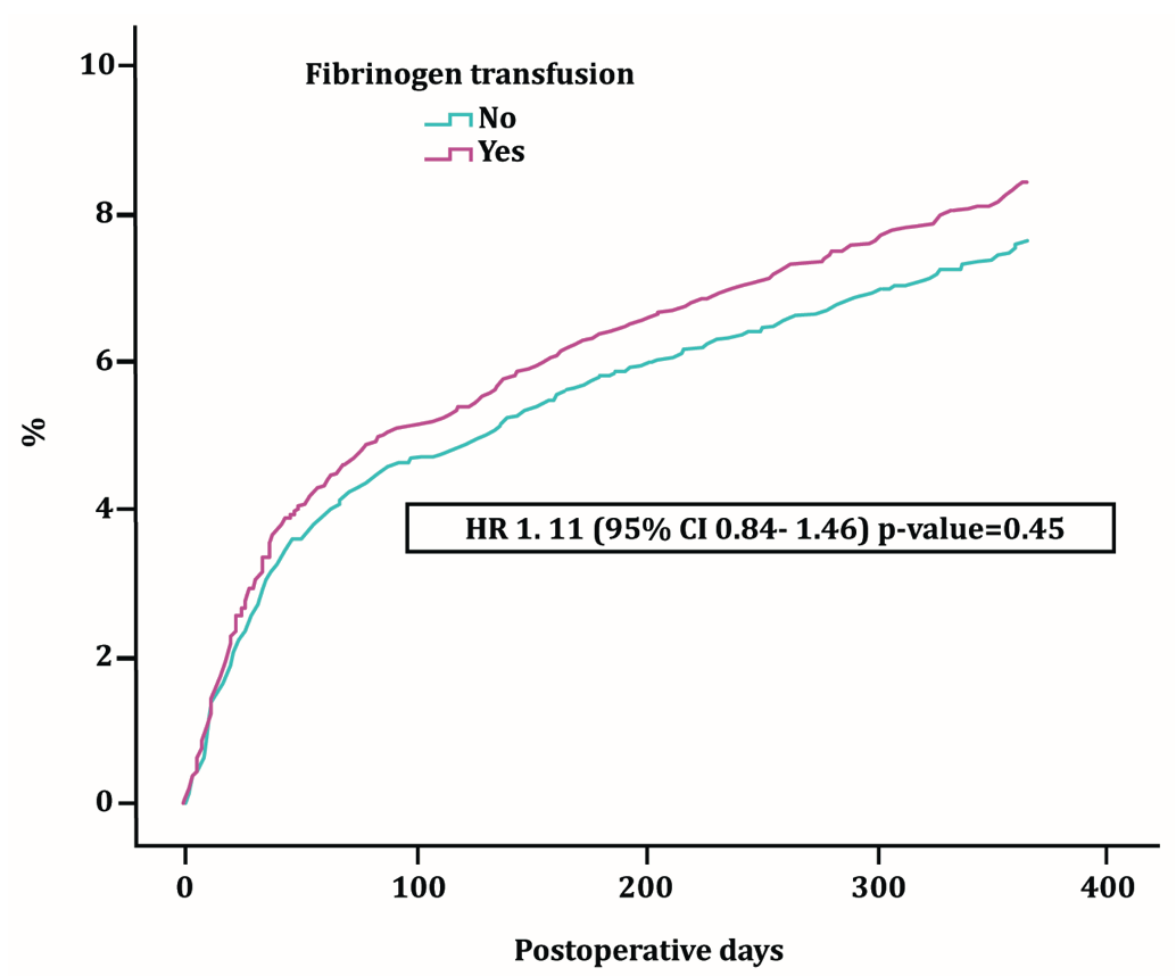

Figure 16. Adjusted incidence of the composite endpoint during the first postoperative year.

\section{0 days outcome}

At 30 days, $3.5 \%$ of the patients had had an event included in the composite endpoint and the mortality rate was $2.3 \%$. The patients who did receive fibrinogen concentrate did not have a significantly higher risk of thromboembolic complications or death after adjustment for covariates, Table 11. 


\begin{tabular}{lcccl} 
End point & $\begin{array}{c}\text { No fibrinogen } \\
(\mathrm{n}=4844)\end{array}$ & $\begin{array}{c}\text { Fibrinogen } \\
(\mathrm{n}=564)\end{array}$ & Odds ratio with 95\% CI & $p$ Value \\
\hline \multirow{2}{*}{ Composite endpoint $^{\mathrm{a}}$} & $\mathrm{n}(\%)$ & $\mathrm{n}(\%)$ & & \\
& $151(3.1 \%)$ & $40(7.1 \%)$ & $2.37(1.65-3.40)^{\mathrm{b}}$ & $<0.001$ \\
Mortality & & & $1.07(0.64-1.81)^{\mathrm{c}}$ & 0.79 \\
& $93(1.9 \%)$ & $32(5.7 \%)$ & $3.07(2.04-4.64)^{\mathrm{d}}$ & $<0.001$ \\
& & & $1.00(0.51-1.96)^{\mathrm{e}}$ & 0.50 \\
\hline
\end{tabular}

Table 11. Associations between fibrinogen concentrate administration and composite endpoint and mortality 30 days after surgery. Odds ratios (OR) based on univariate and multivariable logistic regression models are presented. ${ }^{a}$ Composite endpoint ${ }^{b}$ unadjusted

$O R^{c}$ OR adjusted for age, sex, preoperative antiplatelet therapy, preoperative plasma fibrinogen concentration, platelet count, preoperative serum creatinine, prothrombin time, history of ischemic stroke, CPB time, diabetes, total perioperative transfusions, EuroSCORE 1, surgical procedure dUnadjusted OR for mortality e OR for mortality adjusted for age, sex, preoperative prothrombin time, preoperative fibrinogen concentration, hemoglobin concentration, preoperative platelet count, antiplatelet therapy, preoperative serum creatinine, CPB time, EuroSCORE 1, surgical procedure, total perioperative transfusions.

\subsection{FIBRINOGEN SUPPLEMENTATION AND TRANEXAMIC ACID ADMINISTRATION (IV)}

Median preoperative plasma fibrinogen concentration was 3.3 (2.9-3.6) g/L. The hemoglobin concentration, platelet count, hematocrit and fibrinogen concentration were significantly reduced at the end of surgery. None of the samples showed signs of fibrinolysis after 30 minutes.

Fibrinogen supplementation, with or without the presence of TXA shortened CT and increased MCF, both preoperatively and postoperatively. Before surgery, fibrinogen supplementation shortened CT somewhat more after TXA administration while there was no difference in effect in relation to TXA administration after surgery, Figure 17. The enhancing effect of fibrinogen supplementation on MCF did not differ significantly before and after TXA administration neither before nor after surgery, Figure 18. 


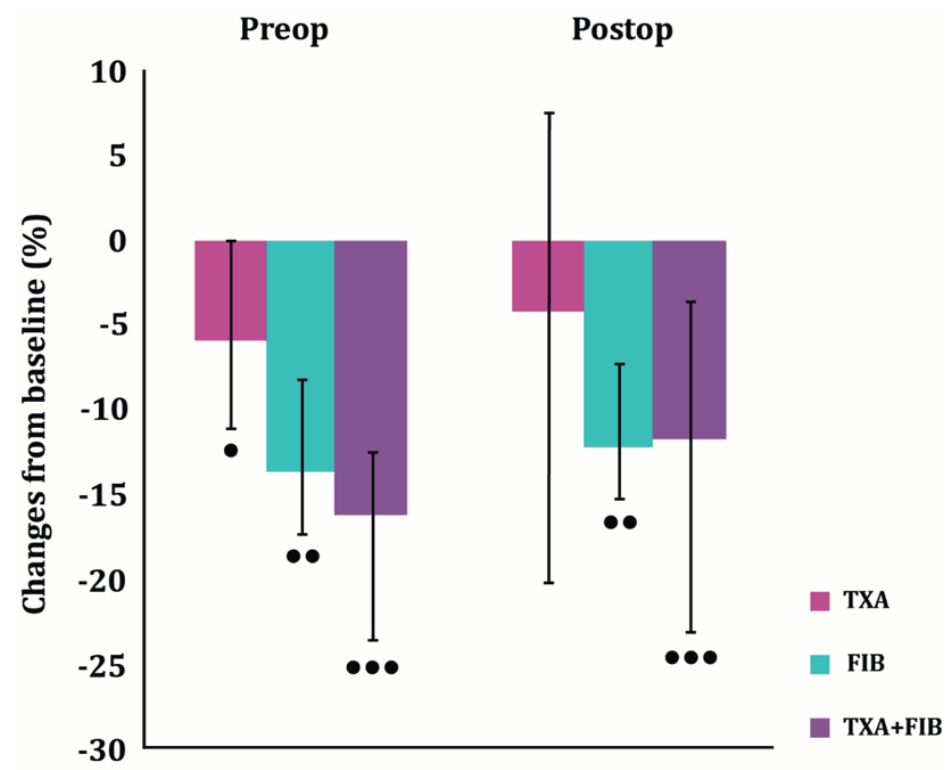

Figure 17. Changes from baseline in CT from after addition of TXA, fibrinogen or both in \%. Baseline CT was 72 (70-78) and 107 (81-118) seconds in the pre-and postoperative samples, respectively. Median and $25^{\text {th }}$ and $75^{\text {th }}$ percentiles. $\bullet p<0.05$, $\bullet p<0.01 \bullet p<0.001$ vs baseline.

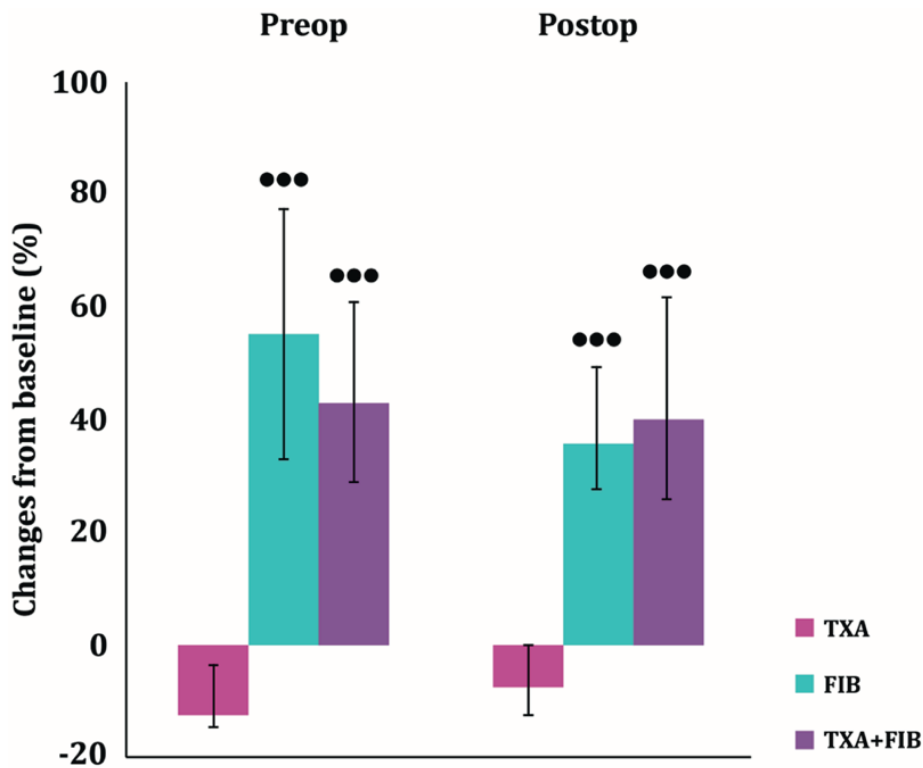

Figure 18. Changes from baseline in MCF after addition of TXA, fibrinogen or both in \%. Baseline MCF was 14 (9-15) and 14 (13-15) $\mathrm{mm}$ in the pre-and postoperative samples, respectively. Median and $25^{\text {th }}$ and $75^{\text {th }}$ percentiles. $\bullet p<0.05$, $\bullet p<0.01 \bullet \bullet p<0.001$ vs baseline. 


\section{DISCUSSION}

\subsection{FIBRINOGEN CONCENTRATION, BLEEDING AND TRANSFUSIONS (I)}

Fibrinogen and its role in hemostasis and bleeding has been thoroughly investigated in the last decade. For many years, a plasma fibrinogen concentration of at least $1.0 \mathrm{~g} / \mathrm{L}$ was considered to be enough to ensure a stable clot formation not limited by fibrinogen concentration in case of bleeding $(21,113)$. In study $\mathrm{I}$, the main finding was that preoperative plasma concentration of less than $2.5 \mathrm{~g} / \mathrm{L}$ was independently associated with increased postoperative bleeding. Fibrinogen levels below the normal reference level are rare in patients without ongoing bleeding and the low prevalence of low fibrinogen levels was confirmed in our cohort. Only $0.4 \%$ of the patients had a fibrinogen concentration below $2.0 \mathrm{~g} / \mathrm{L}$. The question is what endogenous fibrinogen concentration that is sufficient for maintaining a stable coagulation process when the system is challenged during major surgical procedures, like cardiac surgery with $\mathrm{CPB}$ and/or ongoing bleeding. During $\mathrm{CPB}$, there is a decrease in fibrinogen concentration by approximately $30 \%$, mainly caused by hemodilution during CPB $(103,114)$. A preoperative level of $2.5 \mathrm{~g} / \mathrm{L}$, which in our study occurred in about $5 \%$ of the patients, is thereby reduced to approximately $1.75 \mathrm{~g} / \mathrm{L}$, which is under the normal reference range, and on the verge of the level where recent guidelines recommend fibrinogen substitution in case of bleeding (115). Hemodilution also reduces the concentration of other coagulation factors (103). However, supplementation with only fibrinogen concentrate normalized $\mathrm{MCF}$, at least in vitro (114). This indicates that fibrinogen might be a more important limiting factor for whole blood clotting than other coagulation factors and platelets in the case of hemodilution.

In this study, we found a weak ( $\mathrm{r}=-0.17)$, but statistically significant correlation between preoperative concentration of fibrinogen and postoperative bleeding volume, but far too weak to establish any clinical conclusions. This is in contrast to several other studies $(98,100,116)$ and a meta-analysis by Gielen et al (117) which showed stronger correlations. Differences in study populations may explain the variances.

The relationship between low preoperative levels of fibrinogen concentration became more apparent when we instead of overall bleeding volume focused on the risk of excessive bleeding (defined as bleeding 
$>1000 \mathrm{ml} / 12 \mathrm{~h}$ ). The reduction of fibrinogen by $1 \mathrm{~g} / \mathrm{L}$ (one unit), increased the risk of excessive bleeding by $25 \%$, even after correction for other factors that have an impact on postoperative bleeding. Moreover, patients in the group with the lowest levels of fibrinogen, had an almost threefold risk of excessive bleeding compared to the patients with the highest fibrinogen levels. This study thus supports the theory that low plasma fibrinogen concentration is associated with excessive bleeding. But, even if fibrinogen turned out to be an independent predictor of postoperative bleeding, the relative importance of fibrinogen level is difficult to evaluate. The results from the multivariable analyses implicate that other factors such as acute operation, ongoing or recently stopped dual antiplatelet therapy and duration of the operation are more important.

Transfusion of blood products can be lifesaving but it is also related to complications such as acute lung injury, hemolytic reactions, allergic reactions, possible transfer of unknown pathogens and immunomodulation. Over the years, it has been suggested that allogenic blood transfusions lead to increased morbidity and mortality in patients undergoing cardiac surgery. It has in fact been suggested that as little as one or two units of RBCs do increase the mortality risk and severe complications such as infections and ischemic events $(118,119)$. However, the evidence comes from retrospective observational studies where it is difficult to adjust for the worse condition of patients receiving transfusions. More recent prospective randomized studies comparing liberal and restrictive transfusion protocols have shown somewhat diverging results. In the TITRE-2 study (79) the restrictive transfusion protocol was associated with an increased mortality risk, while in the TRICS study (78) no such association was found. Contrarily in the latter study, older patients seem to benefit from a restrictive transfusion protocol, regarding mortality risk.

In study I, univariate analysis indicated that a high preoperative fibrinogen concentration increased the risk of blood transfusion. However, these patients were older, had lower preoperative hemoglobin levels, were more often female and more likely to be undergoing nonelective surgery. All of these are already known risk factors for transfusions. Hence, after adjustment, there was no longer an association between preoperative fibrinogen levels and transfusions. Other studies have however found associations between low fibrinogen concentration and transfusion requirements $(100,101,120)$ while some studies, including study I, have, not found any associations after adjustment for confounding factors $(102,121)$. 
Interestingly, postoperative bleeding volume did not appear to be a risk factor for transfusion. This emphasizes that the decision to transfuse is far more complex than simply substituting a loss of blood. It is therefore a challenge to draw conclusions about bleeding and transfusions, since several of the variables that influence transfusion, are also related to postoperative bleeding volume and low fibrinogen levels.

\subsection{TREATMENT WITH FIBRINOGEN CONCENTRATE (II)}

Two previous small studies from our group have shown an inverse relationship between the preoperative fibrinogen concentration and the postoperative bleeding volume after cardiac surgery $(98,100)$. In 2008 , a small randomized pilot study was conducted, where patients undergoing CABG surgery were randomized to receive either $2 \mathrm{~g}$ of fibrinogen concentrate or nothing before the surgery (105). The study focused on safety aspects including graft patency. The results were in favor of prophylactic fibrinogen supplementation since there was a significant decrease in postoperative bleeding among the patients who had received fibrinogen concentrate. No significant increase in adverse events was detected. Based on these findings, we performed a larger study in study II to further investigate the suggested benefit of prophylactic treatment with fibrinogen concentrate to reduce bleeding and blood transfusions after CABG surgery. However, the results of the pilot study regarding efficacy were not reproduced in the present study. There was no significant difference between the groups regarding postoperative bleeding volume, nor hemoglobin levels, while no safety concerns occurred. The present study had an improved study design (randomized, blinded, placebo controlled) and was carried out on a larger cohort of patients and is thus more valid than the initial pilot study. Hence, the study gives no support for the concept of prophylactic administration of fibrinogen concentrate to low-risk CABG patients with low-normal preoperative fibrinogen levels. This does not exclude that there may be patients who would benefit from prophylactic fibrinogen administration, e.g. those with lower fibrinogen concentrations and/or more complex procedures. In study I, $18 \%$ of the patients with a fibrinogen concentration below $2.5 \mathrm{~g} / \mathrm{L}$ had an excessive postoperative bleeding, when compared to $7 \%$ of the patients with a fibrinogen concentration $\geq 4.6 \mathrm{~g} / \mathrm{L}$. In a group consisting of CABG patients only, the difference was even larger $15 \%$ vs 3.5\%, i.e. a fourfold increase in bleeding among patients with low fibrinogen levels. These large differences indicate that increasing fibrinogen levels might be 
beneficial in patients with really low preoperative fibrinogen concentrations, given the increased mortality risk in patients with excessive bleeding $(62,64)$.

Guidelines from the European Society of Anesthesiology 2013 comprised a recommendation to consider a prophylactic infusion of fibrinogen in patients with a level $<3.8 \mathrm{~g} / \mathrm{L}$ undergoing CABG, based on our pilot study (122). After study II, this recommendation is now withdrawn. Considering the patient cohort with a level under $2.5 \mathrm{~g} / \mathrm{L}$, there might be a rationale for prophylactic treatment, where less than $5 \%$ of the patients would be treated (123).

During the past years, a few prospective randomized studies has been carried out with the notion to use fibrinogen concentrate to reduce bleeding complications and transfusion requirements in cardiovascular surgery (124-126). Most of the studies have been focusing on complex cardiac surgery, with a higher risk of bleeding than the elective CABG patients included in our pilot study and in study II. A significant reduction of both postoperative bleeding volume and transfusion of allogenic blood products was observed in a study carried out on higher risk cardiac surgery patients, where fibrinogen concentrate administration was given after weaning of CPB (125). The median dose was $4 \mathrm{~g}$ and based on calculated target FIBTEM. Another study, with primary endpoint to reduce intraoperative blood loss in complex cardiac surgery (mean dose $3 \mathrm{~g} / \mathrm{L}$, target $>2.5 \mathrm{~g} / \mathrm{L}$ ) after weaning of CPB and before sternum closure did not result in reduced bleeding volume (126). Hence, the question if the use of fibrinogen concentrate might reduce bleeding induced morbidity and mortality is still to be answered. Currently, the recommendation to use fibrinogen concentrate is restricted to patients with ongoing bleeding and probable or confirmed hypofibrinogenemia $(115,127,128)$.

\subsection{FIBRINOGEN ADMINISTRATION AND RISK OF COMPLICATIONS (III)}

In study III, we compared patients who had received fibrinogen concentrate due to bleeding in the perioperative period, with patients who had not received fibrinogen concentrate. The aim of the study was to investigate if administration of fibrinogen concentrate is associated with increased risk of thromboembolic complications and /or death analyzed 
30 days and one year after surgery. A composite endpoint was used and the results showed no increased risk of neither thromboembolic complications nor death within this follow-up time.

Besides its essential effects on hemostasis, elevated fibrinogen levels indicate inflammation and is also a strong marker for cardiovascular disease and mortality. It is well known that increased local aggregation of platelets in atherosclerotic lesions, in which fibrinogen has a major role, is a process that is the beginning of a vaso-occlusive thrombotic event such as myocardial infarction and ischemic stroke. Furthermore, elevated fibrinogen levels are frequently seen in patients with transient ischemic attacks and ischemic stroke (15).

The acute effects on hemostasis and the correlation between elevated plasma concentrations of fibrinogen and cardiovascular disease raise the question whether it is safe to administer fibrinogen as a procoagulant treatment in case of bleeding complications. Further, the potential longterm side effects such as thromboembolic complications when administrating fibrinogen concentrate are not completely known.

Studies focusing on the safety of fibrinogen concentrate administration to reduce perioperative bleeding have shown diverging results. Fassl et al compared two PS-matched groups from an original cohort of 991cardiac surgery patients in which $20 \%$ received fibrinogen concentrate (107). The study did not detect any increased risk of thromboembolic events or mortality within 30 days or at one year. Maeda et al studied a cohort of 1047 patients undergoing thoracic aortic surgery in which $24 \%$ of the patients received fibrinogen concentrate or cryoprecipitate (108). In a PSbased analysis, there was no significant difference in thromboembolic events or mortality at 30 days. In contrast to these two studies, Jakobsen et al found that perioperative administration of fibrinogen was an independent risk factor for postoperative stroke and renal failure in a cohort of 1876 patients of whom $10 \%$ had received fibrinogen concentrate (109).

The present study, which is markedly larger than the previous ones, confirms the results from Fassl's and Maeda's et al $(107,108)$. The conflicting results in Jakobsen's study (109) might be explained by the statistical approach since the results were neither adjusted for excessive bleeding, nor transfusion requirements. In study III we adjusted for transfusion requirements while the study by Fassl et al adjusted for the number of transfused blood products and incidence of major bleeding. It 
is clear from our analyses that the unadjusted mortality and the incidence of thromboembolic events and death were higher in patients who had received fibrinogen concentrate. The difference between the two groups ceased when a multivariable analysis was done. The present results suggest that the higher unadjusted incidence of mortality and thromboembolic complications which was found in fibrinogen treated patients are likely explained by bleeding complications and not by the actual fibrinogen administration per se.

\subsection{EFFECTS OF TRANEXAMIC ACID AND FIBRINOGEN CONCENTRATE (IV)}

Little is known about the potential combined effect of TXA and fibrinogen on hemostasis and bleeding in cardiac surgery. Based on a previous in vitro study by $\mathrm{He}$ et al (129) in which fibrinogen supplementation combined with TXA counteracted fibrinolysis in platelet poor plasma, we investigated if the global hemostatic effects of fibrinogen concentrate analyzed by thromboelastometry were further enhanced in the presence of TXA. The study was conducted using blood samples from cardiac surgery patients. In contrast to our hypothesis, we did not observe any additional effects on clot stability in the presence of TXA. Fibrinogen supplementation, both with and without TXA, had a significant effect on both clotting time and clot stability. One reason might be that the present study was conducted on whole blood with cardiovascular disease compared to platelet poor plasma from healthy donors in the study by $\mathrm{He}$ et al. The effect of patient's preoperative medication such as ASA and different analyzing methods may also be contributing factors.

Improved hemostasis after fibrinogen supplementation has previously been demonstrated in a study by our group, where in vitro fibrinogen administration improved clotting time and clot stability in blood samples from cardiac surgery patients (130). This indicates that fibrinogen per se has a more pronounced effect on clot stability compared to TXA, which would be expected given the different roles of fibrinogen and TXA in the coagulation process. Fibrinogen has a central role in the formation of a clot and substitution of this to diluted blood may therefore stimulate both clot formation and clot stability $(131,132)$. In comparison, TXA reduces fibrin degradation and has in theory no effect on the actual formation of the clot (133). 
TXA as an anti-fibrinolytic drug is used worldwide during cardiac surgery to reduce bleeding and transfusion requirements $(81,134)$. Fibrinogen is increasingly used to treat ongoing bleeding among these patients, based on studies indicating that fibrinogen concentrate can reduce bleeding caused by low fibrinogen levels, hemodilution and thrombocytopenia $(131,132)$. In theory, there is a potential risk that the combination of TXA, which inhibits fibrin degradation, and fibrinogen concentrate might be thromboembolic. The results from He et al might suggest this, but the results from the present study do not. Larger in vivo studies analyzing the combined effect of TXA and fibrinogen in a clinical setting could answer if there is any significant clinical effect.

\subsection{LIMITATIONS}

All four studies were carried out in a single center which raises the question about generalizability. Clinical parameters such as transfusion guidelines, discontinuation of anticoagulation and perioperative drugs may vary between different institutions. Study I and III were both observational studies and there may be inherent limitations such as unrecorded confounding factors and selection bias.

In study I and II, postoperative bleeding volume was the primary endpoint. Bleeding volume is not an ideal endpoint since there are several factors apart from coagulation status that influence postoperative bleeding. Also, unknown confounding factors related to surgery and postoperative intensive care might have an impact on the results. Despite the use of postoperative drainage with container, estimated bleeding volume remains an inconstant measurement. Although other more clinically relevant endpoints such as morbidity and mortality could be more preferable, this would necessitate considerably larger study populations. Several of the variables predicting transfusion were also related to postoperative bleeding volume and low fibrinogen levels, which may obscure the statistical analyses.

In study II, $21 \%$ of the patients received fibrinogen concentrate outside the study protocol which is unusually high for routine CABG surgery with low expected bleeding volume. An explanation may be that the included patients did not receive TXA due to a theoretical risk of increased thromboembolic complications when administrating TXA combined with prophylactic fibrinogen concentrate. The patients in study II also had a 
significantly larger than normal postoperative bleeding volume $(690 \mathrm{ml}$ vs $470 \mathrm{ml}$ ) compared to previously reported bleeding volume in Study I, which might be explained by the lack of TXA. Due to low inclusion rate, study II was stopped prematurely after three years. A total of 48 patients were analyzed instead of 50, which was less than the power calculation implied to prove significance. This may in theory cause a risk of a statistical type 2 error.

Study III was a retrospective study. The indication for administering fibrinogen may differ between treating physicians. Neither was it possible to collect reliable information about perioperative myocardial infarctions from the registries. This potential side effect of fibrinogen concentrate administration could therefore not be analyzed. On the other hand, this is the largest cohort study so far analyzing the effects of fibrinogen concentrate administration and potential thromboembolic complications and death. Furthermore, the registries used, NPR and SWEDEHEART have high validity and are carefully monitored $(111,112,135)$. A prospective randomized controlled study evaluating fibrinogen concentrate in the setting of postoperative bleeding and using thromboembolic complications as endpoint would be more ideal, but might be ethically questionable given the known effect of fibrinogen on hemostasis and the lack of side effect in study III and other studies $(107,108)$.

As study IV was an in vitro study, there is indeed the question to which extent the results are applicable in the clinical setting. Thromboelastometry on whole blood was used to measure clot formation and clot lysis, but the potential interactions of blood vessels and vascular endothelium are lacking. Also, the analyses were performed on blood samples from patients without ongoing excessive bleeding and without fibrinolysis. The results may not be applicable to cardiac surgery patients with ongoing bleeding and/or fibrinolysis. In addition, only the FIBTEMtest was performed, and fibrinolysis was only assessed by measuring maximum clot lysis. These are both selected analyses which display coagulation in part and not the global hemostasis in the patient. 


\section{CONCLUSIONS}

I. Preoperative plasma concentration of less than $2.5 \mathrm{~g} / \mathrm{L}$ is independently associated with increased postoperative bleeding. Preoperative fibrinogen concentration was not associated with RBC transfusion.

II. Preoperative supplementation with fibrinogen concentrate did not reduce postoperative bleeding in CABG patients with low risk of bleeding and normal preoperative fibrinogen concentration.

III. There was no increased risk of thromboembolic complications or death in patients who had received perioperative administration of fibrinogen concentrate.

IV. The enhancing effects of fibrinogen on clot firmness in blood samples from cardiac surgery patients are not further increased in the presence of tranexamic acid. 


\section{FUTURE PERSPECTIVES}

Bleeding and related complications will most probably remain an important issue in cardiac surgery. The quest to find new methods to prevent and handle excessive bleeding will continue. Strategies can include less invasive surgical methods, new treatments to enhance hemostasis in case of bleeding and improved monitoring of perioperative hemostasis. Identifying risk factors for bleeding in cardiac surgery is and will be an ongoing process. In this thesis, the preoperative fibrinogen concentration is identified as a risk factor for excessive bleeding after cardiac surgery, although, the relative importance is difficult to evaluate. Other risk factors are probably more important. Preoperative fibrinogen concentration may therefore be one among many other factors to consider in a preoperative risk evaluation.

The use of fibrinogen concentrate has become an established method to restore and improve hemostasis in case of acquired hypofibrinogenemia due to excessive bleeding. Despite this, the use of fibrinogen concentrate in this setting is in most countries off-label. In contrast, prophylactic administration of fibrinogen concentrate in the absence of ongoing bleeding, especially in low risk procedures, seems not to be of value. Larger, randomized studies would be needed to determine the feasibility of prophylactic fibrinogen concentrate to reduce bleeding and need for blood transfusion in complex, high risk surgery. Also, the timing and dosage of fibrinogen administration would need to be defined.

The safety of fibrinogen use has now been reported in several studies including the present study. Despite this, little is known about the relationship between the actual dose administered to the patient, efficacy and risk of thromboembolic complications. It is in theory possible that larger doses of fibrinogen concentrate may be harmful, and the exact dose in relation to the patient's bodyweight and gender is not known.

We found that a combination of TXA and fibrinogen concentrate had no additive effect compared to fibrinogen alone on clotting time and clot strength when analyzed in vitro. It may be of interest to conduct a trial on cardiac surgery patients with ongoing bleeding since this would add information about the importance of these factors to reduce bleeding. There are also gaps in the evidence regarding how fibrinogen concentrate interacts with already circulating TXA in vivo. 


\section{ACKNOWLEDGEMENTS}

Mitt innerligaste tack till alla som på ett eller annat sätt hjälpt till.

Martin Karlsson. För att du ständigt funnits till hands. För handledning, många skratt, perspektiv på vetenskap och livet i övrigt samt ditt enorma tålamod.

Anders Jeppsson. För ett aldrig sinande engagemang och omtanke. Och för att du av någon anledning trodde på mig när jag som underläkare traskade in på ditt kontor och uttryckte mitt intresse för koagulation.

Sven Egron Thörn. För uppmuntran och kloka synpunkter under arbetes gång.

Alla kompetenta medförfattare.

FoU-gruppen på Thoraxkliniken, däribland forskningssköterskorna Erika Backlund, Christine Roman-Emmanuel och Eva Berg. För stöttning och hjälp med allt möjligt. Inklusive Excelproblem, datainsamling och krånglande maskiner. Caroline Ivarsson. En klippa på alla sätt.

Caroline Shams Hakimi. För att du pedagogiskt guidat mig genom pipettering och labbmetodik.

Salmir Nasic. For statistiska diskussioner och analyser.

Andreas Waldén. För konstnärlig touch på in- och utsida.

Christina Sterner. För språkgranskning när tiden är knapp.

Mina chefer på AnOpIva Östra sjukhuset. För tilldelad tid och forskningsanslag så att denna avhandling kunde bli färdig. Och till alla fina kollegor som gör det roligt att gå till jobbet varje dag, eller natt.

Vladimir Radulovic med kollegor. För lärorika veckor på koagulationscentrum. Och för koagulationsexpertis per mail.

Vänner. Ni vet vilka ni är. Jag skattar mig lycklig som har er.

Min familj. 


\section{REFERENCES}

1. Michelson AD. Platelets. 3th ed. Academic Press, 2013.

2. Schmugge M, Rand ML, Freedman J. Platelets and von Willebrand factor. Transfus Apher Sci 2003;28(3):269-77.

3. Damman P, Woudstra P, Kuijt WJ, de Winter RJ, James SK. P2Y12 platelet inhibition in clinical practice. J Thromb Thrombolysis 2012;33(2):143-53.

4. Leiderman K, Chang WC, Ovanesov M, Fogelson AL. Synergy between tissue factor and exogenous factor XIa in initiating coagulation. Arterioscler Thromb and Vasc Biol 2016;36(12):2334-45.

5. Hoffman M, Monroe DM. Coagulation 2006: a modern view of hemostasis. Hematol Oncology Clin 2007;21(1):1-11.

6. Pieters M, Wolberg AS. Fibrinogen and fibrin: An illustrated review. Res Pract thromb haemost 2019;3(2):161-72.

7. Weisel JW. Fibrinogen and fibrin. Adv protein chem 2005;70:247-99.

8. Kreuz W, Meili E, Peter-Salonen K, Dobrkovska A, Devay J, Haertel S, et al. Pharmacokinetic properties of a pasteurised fibrinogen concentrate. Transfus Apher Sci 2005;32(3):239-46.

9. Collen D, Tytgat GN, Claeys H, Piessens R. Metabolism and distribution of fibrinogen. I. Fibrinogen turnover in physiological conditions in humans. Br J Haematol 1972;22(6):681-700.

10. Standeven KF, Ariens RA, Grant PJ. The molecular physiology and pathology of fibrin structure/function. Blood rev 2005;19(5):275-88.

11. Clauss A. [Rapid physiological coagulation method in determination of fibrinogen]. Acta haematol 1957;17(4):237-46.

12. Stang LJ, Mitchell LG. Fibrinogen. Methods Mol Biol 2013;992:181-92.

13. Blomback B. Fibrinogen and fibrin-proteins with complex roles in hemostasis and thrombosis. Thromb Res 1996;83(1):1-75.

14. Sorensen B, Larsen $\mathrm{OH}$, Rea CJ, Tang M, Foley JH, Fenger-Eriksen C. Fibrinogen as a hemostatic agent. Semin Thrombosis Hemost 2012;38(3):268-73.

15. Davalos D, Akassoglou K. Fibrinogen as a key regulator of inflammation in disease. Semin Immunopathol 2012;34(1):43-62.

16. Kaptoge S, White IR, Thompson SG, Wood AM, Lewington S, Lowe GD, et al. Associations of plasma fibrinogen levels with established cardiovascular disease risk factors, inflammatory markers, and other characteristics: individual participant meta-analysis of 154,211 adults in 31 prospective studies: the fibrinogen studies collaboration. Am J Epidemiol 2007;166(8):867-79.

17. Danesh J, Lewington S, Thompson SG, Lowe GD, Collins R, Kostis JB et al. Plasma fibrinogen level and the risk of major cardiovascular diseases 
and nonvascular mortality: an individual participant meta-analysis. Jama 2005;294(14):1799-809.

18. Besser MW, MacDonald SG. Acquired hypofibrinogenemia: current perspectives. J Blood Med 2016;7:217-25.

19. Hiippala ST, Myllyla GJ, Vahtera EM. Hemostatic factors and replacement of major blood loss with plasma-poor red cell concentrates. Anesth Analg 1995;81(2):360-5.

20. Martini WZ, Chinkes DL, Pusateri AE, Holcomb JB, Yu YM, Zhang XJ et al. Acute changes in fibrinogen metabolism and coagulation after hemorrhage in pigs. Am J Physiol Endocrinol Metab 2005;289(5):E9304.

21. Stainsby D, MacLennan S, Thomas D, Isaac J, Hamilton PJ. Guidelines on the management of massive blood loss. Br J Haematol 2006;135(5):634-41.

22. Martini WZ. Coagulopathy by hypothermia and acidosis: mechanisms of thrombin generation and fibrinogen availability. J Trauma 2009;67(1):202-8.

23. Fenger-Eriksen C, Tonnesen E, Ingerslev J, Sorensen B. Mechanisms of hydroxyethyl starch-induced dilutional coagulopathy. J Thromb Haemost 2009;7(7):1099-105.

24. McLoughlin TM, Fontana JL, Alving B, Mongan PD, Bunger R. Profound normovolemic hemodilution: hemostatic effects in patients and in a porcine model. Anesth Analg 1996;83(3):459-65.

25. Schochl H, Nienaber U, Hofer G, Voelckel W, Jambor C, Scharbert G, et al. Goal-directed coagulation management of major trauma patients using thromboelastometry (ROTEM)-guided administration of fibrinogen concentrate and prothrombin complex concentrate. Crit Care 2010;14(2):R55.

26. Rourke C, Curry N, Khan S, Taylor R, Raza I, Davenport R, et al. Fibrinogen levels during trauma hemorrhage, response to replacement therapy, and association with patient outcomes. J Thromb Haemost 2012;10(7):1342-51.

27. Stinger HK, Spinella PC, Perkins JG, Grathwohl KW, Salinas J, Martini WZ, et al. The ratio of fibrinogen to red cells transfused affects survival in casualties receiving massive transfusions at an army combat support hospital. J Trauma 2008;64(2 Suppl):S79-85

28. Kitchens CS. Consultative Hemostasis and Thrombosis. 4 ed: Elsevier; 2018.

29. Peyvandi F, Palla R, Menegatti M, Siboni SM, Halimeh S, Faeser B, et al. Coagulation factor activity and clinical bleeding severity in rare bleeding disorders: results from the European Network of Rare Bleeding Disorders. J Thromb Haemostasis 2012;10(4):615-21.

30. Neerman-Arbez M, Casini A. Clinical Consequences and Molecular Bases of Low Fibrinogen Levels. Int J Mol Sci 2018;19(1). 
31. de Moerloose P, Schved JF, Nugent D. Rare coagulation disorders: fibrinogen, factor VII and factor XIII. Haemophilia 2016;22 Suppl 5:615.

32. Mosesson MW. Update on antithrombin I (fibrin). Thromb Hemost 2007;98(1):105-8.

33. Remijn JA, Wu YP, Ijsseldijk MJ, Zwaginga JJ, Sixma JJ, de Groot PG. Absence of fibrinogen in afibrinogenemia results in large but loosely packed thrombi under flow conditions. Thromb Haemost 2001;85(4):736-42.

34. Theusinger OM, Baulig W, Seifert B, Emmert MY, Spahn DR, Asmis LM. Relative concentrations of haemostatic factors and cytokines in solvent/detergent-treated and fresh-frozen plasma. Br J Anaesth 2011;106(4):505-11.

35. Rahe-Meyer N, Pichlmaier M, Haverich A, Solomon C, Winterhalter M, Piepenbrock $\mathrm{S}$, et al. Bleeding management with fibrinogen concentrate targeting a high-normal plasma fibrinogen level: a pilot study. Br J Anaesth. 2009;102(6):785-92.

36. Rahe-Meyer N, Sorensen B. For: Fibrinogen concentrate for management of bleeding. J Thromb Haemost 2011;9(1):1-5.

37. Sorensen B, Bevan D. A critical evaluation of cryoprecipitate for replacement of fibrinogen. Br J Haematol 2010;149(6):834-43.

38. Pereira A. Cryoprecipitate versus commercial fibrinogen concentrate in patients who occasionally require a therapeutic supply of fibrinogen: risk comparison in the case of an emerging transfusion-transmitted infection. Haematologica 2007;92(6):846-9.

39. Ghadimi K, Levy JH, Welsby IJ. Perioperative management of the bleeding patient. Br J Anaesth 2016;117(suppl 3):iii18-iii30.

40. Sniecinski RM, Levy JH. Bleeding and management of coagulopathy. The J Thorac Cardiovasc Surg. 2011;142(3):662-7.

41. O'Shaughnessy DF, Atterbury C, Bolton Maggs P, Murphy M, Thomas D, Yates $S$, et al. Guidelines for the use of fresh-frozen plasma, cryoprecipitate and cryosupernatant. Br J Haematol 2004;126(1):1128.

42. Charbit B, Mandelbrot L, Samain E, Baron G, Haddaoui B, Keita H, et al. The decrease of fibrinogen is an early predictor of the severity of postpartum hemorrhage. J Thromb Haemost 2007;5(2):266-73.

43. Fenger-Eriksen C, Lindberg-Larsen M, Christensen AQ, Ingerslev J, Sorensen B. Fibrinogen concentrate substitution therapy in patients with massive haemorrhage and low plasma fibrinogen concentrations. Br J Anaesth 2008;101(6):769-73.

44. Westaby S. Landmarks in cardiac surgery. 1st ed: Oxford Press; 1998.

45. Edmunds LH. Cardiopulmonary bypass after 50 years. N Engl J Med 2004;351(16):1603-6. 
46. Swedeheart Annual Report 2017.

https://www.ucr.uu.se/swedeheart/dokument-sh/arsrapportersh/aeldre-arsrapporter-older-reports/arsrapport-2017/swedeheartannual-report-2017. ( 2019-07-22 Date last accessed.)

47. Greaves SC, Rutherford JD, Aranki SF, Cohn LH, Couper GS, Adams DH, et al. Current incidence and determinants of perioperative myocardial infarction in coronary artery surgery. Am Heart J 1996;132(3):572-8.

48. Biancari F, Anttila V, Dell'Aquila AM, Airaksinen JKE, Brascia D. Control angiography for perioperative myocardial Ischemia after coronary surgery: meta-analysis. J Cardiothorac surg 2018;13(1):24.

49. Hoste EAJ, Vandenberghe W. Epidemiology of cardiac surgeryassociated acute kidney injury. Best Pract Res Clin Anaesthesiol 2017;31(3):299-303.

50. Ozatik MA, Gol MK, Fansa I, Uncu H, Kucuker SA, Kucukaksu S, et al. Risk factors for stroke following coronary artery bypass operations. J Card Surg 2005;20(1):52-7.

51. Cropsey C, Kennedy J, Han J, Pandharipande P. Cognitive Dysfunction, Delirium, and Stroke in Cardiac Surgery Patients. Semin Cardiothorac Vasc Anesth 2015;19(4):309-17.

52. Fowler VG, Jr., O'Brien SM, Muhlbaier LH, Corey GR, Ferguson TB, Peterson ED. Clinical predictors of major infections after cardiac surgery. Circulation 2005;112(9 Suppl):I358-65.

53. Jensen L, Yang L. Risk factors for postoperative pulmonary complications in coronary artery bypass graft surgery patients. Eur J Cardiovasc 2007;6(3):241-6.

54. Sabate S, Mazo V, Canet J. Predicting postoperative pulmonary complications: implications for outcomes and costs. Curr Opin Anaesthesiol 2014;27(2):201-9.

55. Paparella D, Brister SJ, Buchanan MR. Coagulation disorders of cardiopulmonary bypass: a review. Intensive Care Med 2004;30(10):1873-81.

56. Karkouti K, McCluskey SA, Syed S, Pazaratz C, Poonawala H, Crowther MA. The influence of perioperative coagulation status on postoperative blood loss in complex cardiac surgery: a prospective observational study. Anesth Analg 2010;110(6):1533-40.

57. Sniecinski RM, Chandler WL. Activation of the hemostatic system during cardiopulmonary bypass. Anesth Analg 2011;113(6):1319-33.

58. Gielen CL, Brand A, van Heerde WL, Stijnen T, Klautz RJ, Eikenboom J. Hemostatic alterations during coronary artery bypass grafting. Thromb Res 2016;140:140-6.

59. Hansson EC, Jeppsson A. Platelet inhibition and bleeding complications in cardiac surgery: A review. Scand Cardiovasc J 2016;50(5-6):349-54. 
60. Biancari F, Kinnunen EM, Kiviniemi T, Tauriainen T, Anttila V, Airaksinen JKE, et al. Meta-analysis of the Sources of Bleeding after Adult Cardiac Surgery. J Cardiothorac Vasc Anesth 2018;32(4):1618-24.

61. Karthik S, Grayson AD, McCarron EE, Pullan DM, Desmond MJ. Reexploration for bleeding after coronary artery bypass surgery: risk factors, outcomes, and the effect of time delay. Ann Thorac Surg 2004;78(2):527-34

62. Frojd V, Jeppsson A. Reexploration for Bleeding and Its Association With Mortality After Cardiac Surgery. Ann Thorac Surg 2016;102(1):109-17.

63. Ranucci M, Bozzetti G, Ditta A, Cotza M, Carboni G, Ballotta A. Surgical reexploration after cardiac operations: why a worse outcome? Ann Thorac Surg 2008;86(5):1557-62.

64. Dyke C, Aronson S, Dietrich W, Hofmann A, Karkouti K, Levi M, et al. Universal definition of perioperative bleeding in adult cardiac surgery. J Thorac Cardiovasc Surg 2014;147(5):1458-63.e1.

65. Vivacqua A, Koch CG, Yousuf AM, Nowicki ER, Houghtaling PL, Blackstone EH, et al. Morbidity of bleeding after cardiac surgery: is it blood transfusion, reoperation for bleeding, or both? Ann Thorac Surg 2011;91(6):1780-90.

66. Stone GW, Clayton TC, Mehran R, Dangas G, Parise H, Fahy M, et al. Impact of major bleeding and blood transfusions after cardiac surgery: analysis from the Acute Catheterization and Urgent Intervention Triage strategY (ACUITY) trial. Am Heart J 2012;163(3):522-9.

67. Delaney M, Wendel S, Bercovitz RS, Cid J, Cohn C, Dunbar NM, et al. Transfusion reactions: prevention, diagnosis, and treatment. Lancet 2016;388(10061):2825-36.

68. Vincent JL, Sakr Y, De Backer D, Van der Linden P. Efficacy of allogeneic red blood cell transfusions. Best Pract Res Clin Anaesthesiol 2007;21(2):209-19.

69. Wang D, Sun J, Solomon SB, Klein HG, Natanson C. Transfusion of older stored blood and risk of death: a meta-analysis. Transfusion. 2012;52(6):1184-95.

70. Halmin M, Rostgaard K, Lee BK, Wikman A, Norda R, Nielsen KR, et al. Length of Storage of Red Blood Cells and Patient Survival After Blood Transfusion: A Binational Cohort Study. Ann Intern Med 2017;166(4):248-56.

71. Sartipy U, Holzmann MJ, Hjalgrim H, Edgren G. Red Blood Cell Concentrate Storage and Survival After Cardiac Surgery. Jama 2015;314(15):1641-3.

72. Maddux FW, Dickinson TA, Rilla D, Kamienski RW, Saha SP, Eales F, et al. Institutional variability of intraoperative red blood cell utilization in coronary artery bypass graft surgery. Am Journal Med Qual 2009;24(5):403-11. 
73. Klein AA, Collier T, Yeates J, Miles LF, Fletcher SN, Evans C, et al. The ACTA PORT-score for predicting perioperative risk of blood transfusion for adult cardiac surgery. Br J Anaesth. 2017;119(3):394-401.

74. Ferraris VA, Ferraris SP, Saha SP, Hessel EA, 2nd, Haan CK, Royston BD, et al. Perioperative blood transfusion and blood conservation in cardiac surgery: the Society of Thoracic Surgeons and The Society of Cardiovascular Anesthesiologists clinical practice guideline. Ann Thorac Surg 2007;83(5 Suppl):S27-86.

75. Shaw RE, Johnson CK, Ferrari G, Zapolanski A, Brizzio M, Rioux N, et al. Balancing the benefits and risks of blood transfusions in patients undergoing cardiac surgery: a propensity-matched analysis. Interac Cardiovasc Thorac Surg 2013;17(1):96-102.

76. Whitson BA, Huddleston SJ, Savik K, Shumway SJ. Risk of adverse outcomes associated with blood transfusion after cardiac surgery depends on the amount of transfusion. J Surg Res 2010;158(1):20-7.

77. Bhaskar B, Dulhunty J, Mullany DV, Fraser JF. Impact of blood product transfusion on short and long-term survival after cardiac surgery: more evidence. Annals Thorac Surg 2012;94(2):460-7.

78. Mazer CD, Whitlock RP, Fergusson DA, Belley-Cote E, Connolly K, Khanykin B, et al. Six-Month Outcomes after Restrictive or Liberal Transfusion for Cardiac Surgery. N Eng J Med 2018;379(13):1224-33.

79. Murphy GJ, Pike K, Rogers CA, Wordsworth S, Stokes EA, Angelini GD, et al. Liberal or restrictive transfusion after cardiac surgery. N Eng J Med 2015;372(11):997-1008.

80. Myles PS, Smith JA, Forbes A, Silbert B, Jayarajah M, Painter T, et al. Tranexamic Acid in Patients Undergoing Coronary-Artery Surgery. N Eng J Med 2017;376(2):136-48.

81. Henry DA, Carless PA, Moxey AJ, O'Connell D, Stokes BJ, Fergusson DA, et al. Anti-fibrinolytic use for minimising perioperative allogeneic blood transfusion. Cochrane Database Syst Rev 2011(3):Cd001886.

82. McCormack PL. Tranexamic acid: a review of its use in the treatment of hyperfibrinolysis. Drugs. 2012;72(5):585-617.

83. de Haan J, van Oeveren W. Platelets and soluble fibrin promote plasminogen activation causing downregulation of platelet glycoprotein Ib/IX complexes: protection by aprotinin. Thromb Res 1998;92(4):1719.

84. Soslau G, Horrow J, Brodsky I. Effect of tranexamic acid on platelet ADP during extracorporeal circulation. Am J Hematol 1991;38(2):113-9.

85. Jimenez JJ, Iribarren JL, Brouard M, Hernandez D, Palmero S, Jimenez A, et al. Safety and effectiveness of two treatment regimes with tranexamic acid to minimize inflammatory response in elective cardiopulmonary bypass patients: a randomized double-blind, dosedependent, phase IV clinical trial. J Cardiothorac Surg 2011;6:138. 
86. Jimenez JJ, Iribarren JL, Lorente L, Rodriguez JM, Hernandez D, Nassar I, et al. Tranexamic acid attenuates inflammatory response in cardiopulmonary bypass surgery through blockade of fibrinolysis: a case control study followed by a randomized double-blind controlled trial. Crit Care 2007;11(6):R117.

87. Levi M, van der Poll T. Inflammation and coagulation. Crit Care Med 2010;38(2 Suppl):S26-34.

88. Weber CF, Gorlinger K, Byhahn C, Moritz A, Hanke AA, Zacharowski K, et al. Tranexamic acid partially improves platelet function in patients treated with dual antiplatelet therapy. Eur J Anaesth 2011;28(1):57-62.

89. Hartert H. Blutgerinnungsstudien mit der Thromboelastgraphie; einem neuen Untersuchungs Verfahren. Klin Wochenschr 1948;26(3738):577-83.

90. Whiting D, DiNardo JA. TEG and ROTEM: technology and clinical applications. Am J Hematol 2014;89(2):228-32.

91. Romlin BS, Wahlander H, Synnergren M, Baghaei F, Jeppsson A. Earlier detection of coagulopathy with thromboelastometry during pediatric cardiac surgery: a prospective observational study. Paediatr Anaesth 2013;23(3):222-7.

92. Wikkelso A, Wetterslev J, Moller AM, Afshari A. Thromboelastography (TEG) or rotational thromboelastometry (ROTEM) to monitor haemostatic treatment in bleeding patients: a systematic review with meta-analysis and trial sequential analysis. Anaesthesia 2017;72(4):519-31.

93. Romlin BS, Wahlander H, Berggren H, Synnergren M, Baghaei F, Nilsson $\mathrm{K}$, et al. Intraoperative thromboelastometry is associated with reduced transfusion prevalence in pediatric cardiac surgery. Anesth Analg 2011;112(1):30-6.

94. Biancari F, Mikkola R, Heikkinen J, Lahtinen J, Airaksinen KE, Juvonen T. Estimating the risk of complications related to re-exploration for bleeding after adult cardiac surgery: a systematic review and metaanalysis. Eur J Cardiothorac Surg 2012;41(1):50-5.

95. Gravlee GP, Arora S, Lavender SW, Mills SA, Hudspeth AS, Cordell AR, et al. Predictive value of blood clotting tests in cardiac surgical patients. Ann Thorac Surg 1994;58(1):216-21.

96. Wahba A, Rothe G, Lodes H, Barlage S, Schmitz G, Birnbaum DE. Predictors of blood loss after coronary artery bypass grafting. J Cardiothorac Vasc Anesth 1997;11(7):824-7.

97. Liu G, McNicol PL, McCall PR, Bellomo R, Connellan J, McInnes F, et al. Prediction of the mediastinal drainage after coronary artery bypass surgery. Anaesth Intensive Care 2000;28(4):420-6.

98. Aljassim O, Karlsson M, Wiklund L, Jeppsson A, Olsson P, Berglin E. Inflammatory response and platelet activation after off-pump coronary artery bypass surgery. Scand Cardiovasc Journal 2006;40(1):43-8. 
99. Blome M, Isgro F, Kiessling AH, Skuras J, Haubelt H, Hellstern P, et al. Relationship between factor XIII activity, fibrinogen, haemostasis screening tests and postoperative bleeding in cardiopulmonary bypass surgery. Thromb Haemost 2005;93(6):1101-7.

100. Karlsson M, Ternstrom L, Hyllner M, Baghaei F, Nilsson S, Jeppsson A. Plasma fibrinogen level, bleeding, and transfusion after on-pump coronary artery bypass grafting surgery: a prospective observational study. Transfusion 2008;48(10):2152-8.

101. Josefy S, Briones R, Bryant BJ. Preoperative coagulation studies to predict blood component usage in coronary artery bypass graft surgery. Immunohematology 2011;27(4):151-3.

102. Emeklibas N, Kammerer I, Bach J, Sack FU, Hellstern P. Preoperative hemostasis and its association with bleeding and blood component transfusion requirements in cardiopulmonary bypass surgery. Transfusion 2013;53(6):1226-34.

103. Ternstrom L, Radulovic V, Karlsson M, Baghaei F, Hyllner M, Bylock A, et al. Plasma activity of individual coagulation factors, hemodilution and blood loss after cardiac surgery: a prospective observational study. Thromb Res 2010;126(2):e128-33.

104. Bolliger D, Gonsahn M, Levy JH, Williams WH, Tanaka KA. Is preoperative fibrinogen predictive for postoperative bleeding after coronary artery bypass grafting surgery? Transfusion 2009;49(9):2006-7

105. Karlsson M, Ternstrom L, Hyllner M, Baghaei F, Flinck A, Skrtic S, et al. Prophylactic fibrinogen infusion reduces bleeding after coronary artery bypass surgery. A prospective randomised pilot study. Thromb Haemost 2009;102(1):137-44.

106. Solomon C, Groner A, Ye J, Pendrak I. Safety of fibrinogen concentrate: analysis of more than 27 years of pharmacovigilance data. Thromb Haemost 2015;113(4):759-71.

107. Fassl J, Buse GL, Filipovic M, Reuthebuch O, Hampl K, Seeberger D, et al. Perioperative administration of fibrinogen does not increase adverse cardiac and thromboembolic events after cardiac surgery. Br J Anaesth 2015;114(2):225-34.

108. Maeda T, Miyata S, Usui A, Nishiwaki K, Tanaka H, Okita Y, et al. Safety of Fibrinogen Concentrate and Cryoprecipitate in Cardiovascular Surgery: Multicenter Database Study. J Cardiothorac Vasc Anesth 2019;33(2):321-327.

109. Jakobsen CJ TM, Folkersen L. Perioperative Administration of Fibrinogen is Associated with Increased Risk of Thromboembolic Complications after Cardiac Surgery. J Blood Disord Transfus 2011 S1(004).

110. Jernberg T, Attebring MF, Hambraeus K, Ivert T, James S, Jeppsson A, et al. The Swedish Web-system for enhancement and development of 
evidence-based care in heart disease evaluated according to recommended therapies (SWEDEHEART). Heart 2010;96(20):1617-21.

111. Emilsson L, Lindahl B, Koster M, Lambe M, Ludvigsson JF. Review of 103 Swedish Healthcare Quality Registries. J Intern Med 2015;277(1):94-136.

112. Ludvigsson JF, Andersson E, Ekbom A, Feychting M, Kim JL, Reuterwall $\mathrm{C}$, et al. External review and validation of the Swedish national inpatient register. BMC Public Health 2011;11:450.

113. Hellstern P, Muntean W, Schramm W, Seifried E, Solheim BG. Practical guidelines for the clinical use of plasma. Thromb Res 2002;107 Suppl 1:S53-7.

114. Gielen CL, Grimbergen J, Klautz RJ, Koopman J, Quax PH. Fibrinogen reduction and coagulation in cardiac surgery: an investigational study. Blood Coagul Fibrinolysis 2015;26(6):613-20.

115. Kozek-Langenecker SA, Ahmed AB, Afshari A, Albaladejo P, Aldecoa C, Barauskas G, et al. Management of severe perioperative bleeding: guidelines from the European Society of Anaesthesiology: First update 2016. Eur J Anaesth 2017;34(6):332-95.

116. Ucar HI, Oc M, Tok M, Dogan OF, Oc B, Aydin A, et al. Preoperative fibrinogen levels as a predictor of postoperative bleeding after open heart surgery. Heart Surg Forum 2007;10(5):E392-6.

117. Gielen C, Dekkers O, Stijnen T, Schoones J, Brand A, Klautz R, et al. The effects of pre- and postoperative fibrinogen levels on blood loss after cardiac surgery: a systematic review and meta-analysis. Interac Cardiovasc Thorac Surg 2014;18(3):292-8.

118. Paone G, Likosky DS, Brewer R, Theurer PF, Bell GF, Cogan CM, et al. Transfusion of 1 and 2 units of red blood cells is associated with increased morbidity and mortality. Ann Thorac Surg 2014;97(1):87-93.

119. Murphy GJ, Reeves BC, Rogers CA, Rizvi SI, Culliford L, Angelini GD. Increased mortality, postoperative morbidity, and cost after red blood cell transfusion in patients having cardiac surgery. Circulation 2007;116(22):2544-52.

120. Prohaska W, Zittermann A, Inoue K, Tenderich G, Luth JU, KosterEiserfunke W, et al. Preoperative haemostasis testing does not predict requirement of blood products in cardiac surgery. Eur J Med Res 2008;13(11):525-30.

121. Pillai RC, Fraser JF, Ziegenfuss M, Bhaskar B. Influence of circulating levels of fibrinogen and perioperative coagulation parameters on predicting postoperative blood loss in cardiac surgery: a prospective observational study. J Card Surg 2014;29(2):189-95.

122. Kozek-Langenecker SA, Afshari A, Albaladejo P, Santullano CA, De Robertis E, Filipescu DC, et al. Management of severe perioperative bleeding: guidelines from the European Society of Anaesthesiology. Eur J Anaesth 2013;30(6):270-382. 
123. Ranucci M, Jeppsson A, Baryshnikova E. Pre-operative fibrinogen supplementation in cardiac surgery patients: an evaluation of different trigger values. Acta Anaesthesiol Scand 2015;59(4):427-33.

124. Rahe-Meyer N, Levy JH, Mazer CD, Schramko A, Klein AA, Brat R, et al. Randomized evaluation of fibrinogen vs placebo in complex cardiovascular surgery (REPLACE): a double-blind phase III study of haemostatic therapy. Br J Anaesth 2016;117(1):41-51.

125. Ranucci M, Baryshnikova E, Crapelli GB, Rahe-Meyer N, Menicanti L, Frigiola A. Randomized, double-blinded, placebo-controlled trial of fibrinogen concentrate supplementation after complex cardiac surgery. J Am Heart Ass 2015;4(6):e002066.

126. Bilecen S, de Groot JA, Kalkman CJ, Spanjersberg AJ, Brandon Bravo Bruinsma GJ, Moons KG, et al. Effect of Fibrinogen Concentrate on Intraoperative Blood Loss Among Patients With Intraoperative Bleeding During High-Risk Cardiac Surgery: A Randomized Clinical Trial. Jama 2017;317(7):738-47.

127. Boer C, Meesters MI, Milojevic M, Benedetto U, Bolliger D, von Heymann C, et al. 2017 EACTS/EACTA Guidelines on patient blood management for adult cardiac surgery. J Cardiothorac Vasc Anesth 2018;32(1):88120.

128. Practice guidelines for perioperative blood management: an updated report by the American Society of Anesthesiologists Task Force on Perioperative Blood Management*. Anesthesiology 2015;122(2):24175.

129. He S, Johnsson H, Zabczyk M, Hultenby K, Wallen H, Blomback M. Fibrinogen depletion after plasma-dilution: impairment of proteolytic resistance and reversal via clotting factor concentrates. Thromb Haemost 2014;111(3):417-28.

130. Shams Hakimi C, Fagerberg Blixter I, Hansson EC, Hesse C, Wallen H, Jeppsson A. Effects of fibrinogen and platelet supplementation on clot formation and platelet aggregation in blood samples from cardiac surgery patients. Thromb Res 2014;134(4):895-900.

131. Fries D, Innerhofer P, Reif C, Streif W, Klingler A, Schobersberger W, et al. The effect of fibrinogen substitution on reversal of dilutional coagulopathy: an in vitro model. Anesth Analg 2006;102(2):347-51.

132. Lunde J, Stensballe J, Wikkelso A, Johansen M, Afshari A. Fibrinogen concentrate for bleeding--a systematic review. Acta Anaesthesiol Scand 2014;58(9):1061-74.

133. Ng W, Jerath A, Wasowicz M. Tranexamic acid: a clinical review. Anaesthesiol Intensive Ther 2015;47(4):339-50.

134. Esper SA, Subramaniam K, Tanaka KA. Pathophysiology of Cardiopulmonary Bypass: Current Strategies for the Prevention and Treatment of Anemia, Coagulopathy, and Organ Dysfunction. Semin Cardiothorac Vasc Anesth 2014;18(2):161-76. 
135. Vikholm P, Ivert T, Nilsson J, Holmgren A, Freter W, Ternstrom L, et al. Validity of the Swedish Cardiac Surgery Registry. Interact Cardiovasc Thorac Surg 2018;27(1):67-74. 